\title{
Measuring "equivalent living conditions"? The use of indicators in German federal spatial planning
}

\author{
Walter Bart* and Christian Papilloud \\ Martin Luther University Halle-Wittenberg, Institute of Sociology, Halle, Germany
}

\begin{abstract}
It is commonly claimed that the use of numbers and indicators in society is on the rise. Yet, it is still unclear why numbers are used in some social fields but not in others. This paper investigates the specific use of indicators in the policy field of federal spatial planning in Germany. While the use of indicators is very common in this area, the guiding idea of equivalent living conditions has not been operationalized with an agreed on set of indicators nor do particular policy instruments targeting 'unequivalent' living conditions exist. Why is this the case? Drawing on literature about the use of scientific knowledge in politics as well as on social studies of quantification processes, we argue that regular monitoring of regional disparities has increased the political salience of the idea of equivalent living conditions. At the same time, a more systematic formalization of this idea has been hampered, firstly, by the entangled competencies of German federalism and secondly, by the ambiguous idea of equivalent living conditions which has faced competition by the more narrowly defined concept of regional economic development and the related GDP indicator.
\end{abstract}

Keywords: Social studies of quantification, governing by numbers, spatial justice, territorial justice, spatial planning, federalism, topic modeling

\section{Introduction}

It is commonly claimed that the use of numbers and indicators in society is on the rise [1-6]. While there seems to be a widespread consensus that this trend is occurring, the debate about its causes and consequences is far more controversial. In particular, it is still unclear why numbers are used in some social fields but not in others. Similarly, we do not know why some indicators have become central to the governance of some social fields while other indicators are not being used at all. Research on indicators has tended to focus much more on the genesis of indicators rather than on their actual use or non-use in society. As a consequence, we know little about the different forms of using indicators in politics and how to explain them. This paper investigates the specific use of indicators in the policy field

\footnotetext{
${ }^{*}$ Corresponding author: Walter Bartl, Martin Luther University Halle-Wittenberg, Institute of Sociology, Emil Abderhaldenstr. 2627, 06108 Halle (Saale), Germany. Tel.: +49 1781481551; E-mail: walter.bartl@soziologie.uni-halle.de.
}

of federal spatial planning in Germany. In particular it focuses on the question of why the guiding idea of equivalent living conditions (gleichwertige Lebensverhältnisse), codified in the country's Basic Law (Art. 72 GG) and other, more specific legal sources, has yet to be operationalized with an agreed set of key indicators. Why is there neither formal monitoring of 'unequivalent' living conditions nor any formal policy instruments explicitly targeting this guiding idea? This is all the more astonishing since the field of spatial planning is generally deeply imbued with indicators. For example, the Spatial Planning Report (Raumordnungbericht) is used by the federal government as a monitoring device in this policy field and hence would be expected to be a quasi-natural outlet for such an endeavor.

By focusing on federal spatial planning in Germany, this paper aims to shed light on a traditional 'market' segment for official statistics in which the use of indicators has been fairly common. At the same time, only rarely has the guiding principle of equivalent living conditions sparked major political debate and it has yet to lead to the institutionalization of a federal 
funding scheme explicitly targeting equivalent living conditions. Like the idea of territorial cohesion at the EU-level, the concept is notoriously ambiguous and difficult to operationalize $[7,8]$. Nevertheless, a political and academic debate on measuring equivalent living conditions has recently gained momentum $[9,10]$. Public attention peaked when the German government assigned an Equivalent Living Conditions Commission with the task of establishing a common understanding of equivalent living conditions and evaluating territorial disparities regarding this aspect. The commission's report was approved by the federal government in July 2019 but is still awaiting approval of the German states (Länder) and the local government associations. This report was accompanied by a so-called Atlas of Germany (Deutschlandatlas) containing 54 descriptive indicators that are meant to support the endeavor of reaching a common understanding of equivalent living conditions [7]. Our argument is twofold: First, we propose that the sustained quantitative description and interpretation of regional disparities - such as in the Spatial Planning Report - has increased the political salience of a place-based problematization of these developments in terms of the normative concept of equivalent living conditions. Second, while proposals to operationalize the idea of equivalent living conditions do exist, they have yet to be taken up by politicians, for example through setting up regular monitoring or design of formal policies explicitly targeting equivalent living conditions. In the theoretical part of this paper we develop a heuristic that allows us to analytically distinguish between different forms of indicator use in politics. We explain the hitherto limited quantitative formalization of policies targeting 'unequivalent' regional living conditions against the backdrop of competition between policy concepts and formally related quantitative indicators. Furthermore, the parallel development of rather informal ways of policy formulation in federal spatial planning, such as 'model projects' [11], has complemented the strict formalization of regional equalization policies. The informal use of indicators in model projects, which integrates scientific experts and policymakers, seems to be highly compatible with the entangled competencies of Germany's federal system.

The paper is structured as follows: First, we will present theoretical considerations explaining the use of indicators in politics as well as their effects. Then, we will describe our methodological approach. In order to analyze the evolution of the limited use of quantitative indicators for the operationalization of the idea of equivalent living conditions, the paper will examine the content of sixteen Spatial Planning Reports published between 1963 and 2017 using quantitative and qualitative methods [12-26]. In a subsequent step we will summarize the results of the empirical analysis and discuss these results against the backdrop of our assumptions derived from the theoretical literature. The paper concludes by deliberating on how insights from the historical analysis of the limited use of indicators in German federal spatial planning can be applied to official statistics in the future.

\section{The use of indicators in politics}

Governance depends on knowledge. A political system can draw upon external experts or build up expertise internally in order to acquire the required knowledge for making decisions [27]. Expertise comes in different forms. Expert knowledge can be tacit knowledge, or it can be objectified in the form of words, numbers and artifacts. Weber's ideal type of bureaucracy as a rational form of domination hinges very much on the professional knowledge of internal experts [28]. Similarly, as a specific form of knowledge, indicators can be generated within the political sphere or they can be provided by external experts, such as scientists or consultants. National institutes of statistics and other producers of territorial indicators are, in fact, organizational hybrids as they are concurrently exposed to both scientific and political expectations [29]. Since numbers have an aura of objectivity, they are often in high demand when the generation or restoration of public trust is at stake $[3,30]$. Yet, numbers only maintain their aura of objectivity if the organization providing them is perceived as being sufficiently independent from particularistic interests [31]. Accordingly, experts working in organizations where science and politics intersect typically regard themselves as being scientific. At the same time, if the design of indicators becomes too detached from the needs of policymakers, they are more likely to be ignored [32]. How can we account for the use or non-use of indicators in politics?

\subsection{The use of scientific knowledge in politics}

In order to approach this question, we first consider conceptions of the use of scientific knowledge and check how they might help in developing a definition of different forms of indicator use in politics. The aspect of using scientific knowledge in politics was originally interpreted in a narrow instrumental sense, conceptualiz- 
ing the relationship between science and politics within an "engineering model" [33]. It assumed that there was an instrumental relationship between the two spheres, implying well-defined problems on the side of policymakers and ready-made (quantitative) research results for problem solving on the side of scientists. Scientific results would be put to immediate use and directly lead to concrete policy decisions. The scholars of regional studies using this framework then called for stricter adherence to social science norms: conceptual coherence, causal theory and empirical tests of theory [34]. However, policy issues are very often ill-defined [35,36]. In fact, controversy may arise about the nature of the conditions claimed to be problematic as well as the standards used to evaluate them, proposed solutions and possible alternatives [37]. In the process of defining a problem, indicators can be used to objectify claims but also to deliberate on possible solutions.

Empirical research very soon supplemented the narrow conception of knowledge use with the "enlightenment model", which proposed a much broader theoretical approach [38]. The enlightenment model acknowledged that scientific knowledge may influence policy in direct as well as in more indirect and incremental ways by reframing the issues at stake. This conceptual influence of scientific knowledge is often channeled through mass media. It has been claimed that the EU-concept of territorial cohesion exerts such a conceptual influence despite its fuzziness [8]. We propose that, in a similar way, regular reporting on regional disparities may influence the framing of certain public issues (through mass media) and hence political decision making.

It has also been observed that scientific knowledge can be used to legitimate preconceived policy goals, in other words, after a decision has been made. This has been defined as a symbolic or political use of knowledge. Since collectively binding decisions on the official operationalization of equivalent living conditions have yet to be made, this category appears to be of minor importance. A fourth aspect of knowledge use refers less to the impact of results than to how these results are generated in the first place. When policy knowledge is generated in a participatory way, the process of co-production by different stakeholders makes the resulting knowledge not only relevant for policy, but also enhances its legitimacy [39]. While the Spatial Planning Report is generated by the Federal Institute for Research on Building, Urban Affairs and Spatial Development (BBSR), some of the institute's more recent activities, which strive to develop a measurement concept for equivalent living conditions, are explicitly designed to integrate decision makers as well [40]. Before we can determine how fruitful these analytical distinctions of knowledge use are, we have to consider in more detail the specificity of indicators as a particular form of knowledge.

\subsection{Formal and informal uses of indicators in politics}

Numbers and indicators are perceived as being at the heart of modern government technologies [4]. Studies on the history of statistics argue that official indicators have allowed for the formation of informational capital of bureaucracy, a necessary precondition for war making or social interventions [41-43]. Statistics generate abstract knowledge that can travel large distances and can be accumulated in centers of decision making [44]. When examining the most common explanations for the rise of official statistics, a quantitative study of 157 countries showed that war making was the main driver behind the establishment of national statistical systems in the $19^{\text {th }}$ century, whereas in the $20^{\text {th }}$ century democratization, economic development, colonialism and de-colonization, and ties to international organizations were more important [2]. In the absence of a 'world state', international organizations, in particular, use indicators to make global issues governable because the responsibility for reaching numerical targets lies with the addressee, the nation state, not the rule-setting body [6]. A common denominator of the interdisciplinary research on the history of statistics is that the resulting indicators do not merely describe the world in a neutral way but rather transform it by rendering it knowable and governable [45]. This position was probably established most clearly by actor-network theory [4,45]. Racial classification in Latin America, for example, did not simply reflect the socio-demographic composition of the population but responded to the expectations of a global audience of other nation states [46]. The depiction of these characteristics, in turn, affected public policies. Another example is the practice of colonial census taking in India and the publication of the results, which raised the Hindu and Muslim consciousness [47]. However, the non-use of existing indicators in certain social fields is rarely accounted for [48]. Why are there no standard indicators for the measurement of equivalent living conditions even though plenty of indicators are being used to describe regional disparities? Existing case studies from ethnic statistics point to political conflicts over the institutionalization of indicators as a possible explanation for the non-use of indicators [49,50]. Furthermore, 
since issues and indicators compete for attention, it is difficult to deduce which indicators are more likely to be selected or substituted with new ones in politics. This is all the more unsatisfactory since there is obviously considerable (synchrone and diachrone) variance in the use of particular indicators. As the number of indicators has historically increased, the competition among them has become more intense.

At least three types of arguments attempt to explain the ups and downs of the use or non-use of indicators: The first one maintains that certain features of the indicators themselves are decisive while the second one attributes the observed variance to the social context in which indicators are embedded [48,51]. The third argument hinges on an interactive process between the features of a given type of indicator and its political environment, sometimes resulting in their complementarity [41,52].

With regard to the first argument, it is usually assumed that indicators have to fulfil certain quality criteria in order to embody epistemic authority [1]. Of the many different quality criteria, validity, in other words, the idea that the observed phenomena should correspond to the concept that they profess to operationalize, seems to be of understandable importance [53]. Ideally, this validity should be intelligible not only to experts but also intuitively to a wider public. For this reason, the names of indicators typically reveal what they intend to measure [54]. One could say that their names re-translate the meaning of numbers into words. Depending on the concept to be measured, indicators can be merely descriptive, part of a causal model, and/or intended to operationalize a normative model [55]. In any case, the correlation between the concept and the indicator, a set of indicators or an index is something that is established by correspondence rules. In the framework of instrumental knowledge use, it is typically the quality of indicators that becomes the subject to research activities [56].

With regard to the second argument, attributing the use or non-use to the context of the indicator [51], it is useful to more carefully consider the specific features of indicators as a form of knowledge: Indicators formalize and standardize the representation of the world by a process of quantification $[57,58]$. What was once unobserved becomes visible, what was formerly expressed in words is translated into numbers [59]. The rules of observation decided upon in the production process reduce personal discretion in the description and interpretation of the world. Formalization can be further extended into the political sphere when a periodical monitoring process is set up or when indicators become related to positive or negative sanctions or both. Then, indicators become political instruments [60]. Rule setting, monitoring and sanctions are elements of formal organizations that can also be used outside of formal organizations [61]. Hence, organizational elements that are based on indicators have a formalizing or standardizing effect on society even without the establishment of a formal organization. If a cognitive or normative concept is explicitly operationalized and is monitored periodically through public indicators, alternative descriptions automatically compete with the descriptions of the established reports. Challenging a monitoring report based on official indicators would probably require building up evidence based on 'better' numbers. When the allocation of public resources becomes subject to "statistical rules" rather than political negotiation and discretion, personal power is reduced [62] - a feature that is not always welcomed by decision makers. In this sense, the non-use of energy sector indicators has been attributed to the interests of stakeholders in UK energy policy [51].

The third type of argument, pointing to a complementary relationship between indicators and their societal environment, can be found, to a certain extent, in most studies on the history of statistics and indicators. In our view, it has been presented most explicitly by Alain Desrosières, who developed a typology of indicators and the historical periods in which they were predominantly used [59]. His more general argument is that the legitimacy of indicators depends on complementary normative ideas as well as the political language of a particular historical period [41]. A similar concept of co-emergence of calculative practices and a corresponding legitimizing vocabulary is used in the social studies of accounting [63]. Complementary relationships between indicators and their interpretation can emerge quasi-naturally, but they can also be purposefully created by investments in forms [64]. In such an investment process, the effort required for categorization and association can be reduced if existing forms of high generalization can be built upon.

There has not been much research on the use or influence of indicators in German federalism. Previous studies on the entanglement of competencies in German federalism have found that the federal states prefer fairly stable allocation quotas for the 'just' distribution of central government funds. This has been explained by the ability of these schemes to stabilize expectations and minimize conflicts among the recipients $[65,66]$. These quota schemes - such as population shares of 
individual states - have been preferred even over alternative, supposedly more targeted indicators for the distribution of federal funds because they create fictitious equality among states that are obviously unequal (e.g. in size). The need for conflict minimization is greater in spatial planning policy than in more narrowly defined fields like economic spatial policy [65].

In summarizing the main points of our theoretical analysis, we conclude that the use of indicators in politics can take several forms:

a. no explicit formal operationalization of a descriptive, causal or normative concept, but a gradual quantitative (re)framing of the concept in question that signals an implicit convergence of interpretations (informal use of indicators),

b. the explicit operationalization of a concept by setting up correspondence and measurement rules (formalization I),

c. the inclusion of agreed upon indicators (as in formalization I) into a periodical monitoring system (formalization II),

d. the linking of these indicators with rules for the allocation of financial obligations and benefits (formalization III).

The forms of indicator use that we distinguish between vary in the degree to which they establish formalized chains of observation and collective decision making by linking them to each other in a meaningful way. Stage a) denotes the lowest level of formalization while stage d) denotes the highest level of formalization that we consider in this paper. Reiterating the distinction between instrumental use and conceptual influence of scientific knowledge, stage d) would be more akin to an instrumental use of knowledge with clearly defined problems and solutions becoming linked to each other through statistical rules. Lower levels of formalization (stages a-c) would roughly correspond to a conceptual influence of indicators.

Alt hough these stages are conceptualized as ordinals, this is just a heuristic distinction. We have no compelling reasons to assume there is any quasi-natural progress driving indicator use upwards on this scale. However, we would assume that indicators that are used in a merely descriptive way are less likely to lead to higher degrees of formalization than indicators that have been integrated into a robust causal model. Indicators that have become subject to causal attributions are more likely to become part of the formal instrumentation of normative political aims since they suggest governability of the measured phenomenon. Although the formal instrumentation of normative political aims does not necessarily need to be based on causal indicators, we speculate that these formalizations might be more stable than those which are based on merely descriptive indicators. The gross domestic product (GDP), for example, has been integrated into many causal models and is also a decisive criterion for the allocation of regional economic policy funds $[67,68]$.

\section{Data and methods}

\subsection{Official documents and participant observation}

In order to gain an overall impression of the historical dimension of political attention towards the current public issue of equivalent living conditions, we conducted a keyword search in the database of the German parliament [69]. We used the logical operator 'Gleichwertig* Lebensverhältnisse' to capture references to the principle of equivalent living conditions and the keyword 'Raumordnungsbericht' for references to one of the 16 Spatial Planning Reports published between 1963 and 2017. By early December 2019, the two keywords were mentioned in 1,406 plenary minutes and other printed matter.

We also used the 16 Spatial Planning Reports (19632017) that have been published so far as a source of information and we participated in two recent workshops on the topic of equivalent living conditions $[40,70]$.

\subsection{Mixed-methods content analysis}

Our methodological approach consisted of a combination of quantitative and qualitative methods [71]. First, we analyzed the 16 Spatial Planning Reports using the topic modeling tool Multi-Text Analyser (MTA) programmed in Python 3.x [72]. This allowed us to receive an exploratory impression of the topics that were dealt with in these documents. Next we validated the results obtained by the topic model with qualitative and quantitative content analysis [73,74]. The rationale for using words to analyze the use of numbers is that words convey the meaning of numbers.

A topic model provides a number of word lists which can be interpreted as themes based on fields of words which are called topics. For example, we can take a word pair consisting of the words A and B - such as milk and cat - which often occur together in several documents. The information that $\mathrm{A}$ and $\mathrm{B}$ often occur together in these documents can tell us something about the content of the documents and the use of $\mathrm{A}$ and $\mathrm{B}$ in 
these documents. Now, let us assume that there are other word pairs consisting in the words A, B, C and D. All six word pairs based on these words $(\mathrm{AB}, \mathrm{AC}, \mathrm{AD}, \mathrm{BC}$, $\mathrm{BD}, \mathrm{CD})$ also occur frequently in the documents. If the documents with these word pairs are, for the most part, similar types of documents, it can be assumed that there is a connection between these words, word pairs and documents. A topic model illustrates this relationship by representing groups of words - the topics - that often occur together in several documents, and it enables us to estimate the frequency of other word combinations in these documents - the model. If this estimate only produces minor errors, then we can assume that using a topic model to represent word statistics makes sense.

We used a topic modeling strategy based on a nonnegative matrix factorization (NMF) algorithm in contrast to topic models based on other algorithms like the Bayesian models of Latent Dirichlet Allocation (LDA) developed in the field of machine learning [75]. NMF models analyze documents in a similar fashion to cluster and factor analysis in the sense that they use a word matrix to reduce the dimensions of the documents. This matrix is approximated through the product of two lowrank non-negative matrices, where the first low-rank matrix contains the topics, and the second low-rank matrix establishes the weight of such topics. In other words, NMF models decompose each document in a dataset into a weighted sum of topics representing a weighted collection of words. Like LDA, NMF enables topic models to be built which can be represented as 'matrix factorization' procedures, or as procedures factorizing a matrix of documents via words entries. One major difference between the mathematical definition of NMF and other topic models is that NMF optimizes the decomposition of the documents via a word matrix so that the entire document-word matrix, including zero entries, can be well approximated. These entries usually represent the absence of words in documents, which, in empirical settings, typically exceeds the number of positive entries by several orders of magnitude. In contrast, LDA for example, which is based on Gibbs sampling, optimizes the decomposition of the documents via word matrices which allows us to obtain a vector of probabilities for each occurring word. This explains how likely this word is to belong to each of the topics estimated during the topic model analysis.

Due to the way in which topic models process textual data based on the factorization of a - usually weighted matrix of documents via words (the so called "bag of words" approach), these models do not correspond to a common sense notion of the themes included in the documents. Therefore, the output contrasts with a manual content analysis but it is nonetheless supposed to converge with the human intuition of the themes included in the documents analyzed. In our case, we used the term-frequency-inverse-document-frequency-score (TF-IDF) in order to weight our matrix. This score is applied to each word occurring in the documents. It is the product of two factors: the frequency that a word occurs in a document and the inverse document frequency (IDF) value of that word. The IDF value is high if a word is very specific and only occurs in a few documents. It is low if a word occurs in almost all of the documents.

In order to fine-tune our topic model analysis, we used two complementary cross-validation procedures included in the MTA tool. The first one uses the framework of cluster analysis with the K-Means++ algorithm which we ran for a number of clusters going from 2 to 20. During each run, we checked the scores based on the Bayesian information criterion (BIC), silhouette, David Bouldin, and the log-likelihood score in order to deduce the optimal number of topics. The second cross-validation procedure used the word $2 \mathrm{vec}$ algorithm provided by the gensim package for Python in order to build clusters based on the semantic similarity of the words used in the documents [76]. Both crossvalidation procedures led to the estimation of five relatively stable topics establishing the five most important constellations of words and of related themes discussed in the documents. The solution of five topics and their distribution across documents proved to be robust even when we changed the window of observation (the basic semantic unit as number of words used to define the vector space in texts), e.g. from 40 to 10 words. The results presented in the following section where obtained with a window of observation of 40 words.

Coding for the qualitative content analysis and frequency counts was done using the software MAXQDA [73]. The coding process focused first on the word-phrase 'equivalent living conditions' and semantically related terms. In a second step we also coded and manually traced selected words that were assessed as being salient from the topic model in order to validate our interpretations.

\section{The idea of equivalent living conditions and the monitoring of regional disparities}

Although the Spatial Planning Act of 1965 that formally institutionalized the policy field of spatial plan- 

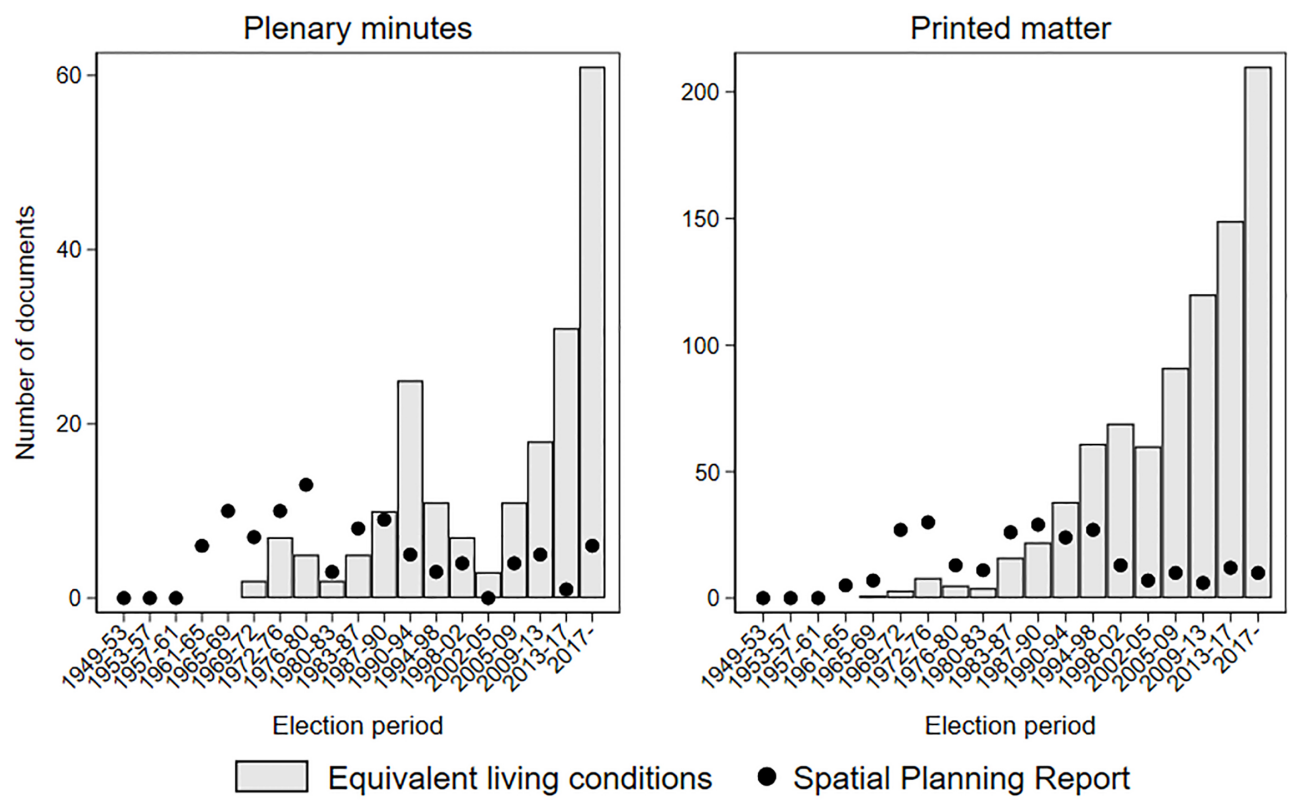

Fig. 1. Number of documents of the German parliament mentioning equivalent living conditions or the Spatial Planning Report (Source: Deutscher Bundestag [69].

ning (Raumordnung [77]); on the federal level did not mention the exact phrase 'equivalent living conditions', the origin of its guiding idea can be traced back to the Weimar Republic in the 1920s [78]. The Spatial Planning Act aimed to balance out unequal living conditions between rural areas and agglomeration zones. The main instrument was to foster the performance capacity of rural areas and the zone bordering the former German Democratic Republic (GDR) so that living and working conditions as well as economic and social structures would be on a level that was "at least equivalent to the rest of the federal territory" (translated from [79]). Hence, the act basically contained the normative ideal of a sedentary population. Mobility - especially outmigration from economically weak areas - was regarded as rather unruly behavior [80]. In a certain sense, it mirrored the harmonious worldview of key spatial planners who had been socialized professionally in the Weimar Republic and in the Third Reich and who had been lobbying since the 1950s for this act [78,81].

A more systematic political use of the term 'equivalent living conditions' did not occur until the Federal Program of Spatial Planning of 1975. It aimed at improving the quality of life in all subspaces of the Federal territory in order to assure equal chances for all citizens. The federal government had already been instructed by the German parliament in 1969 to set up a program that would "regulate the allocation of federal funds with spatial effects based on a concrete spatial target sys- tem" (translated from [79]). In the empirical part of this paper, we will begin by analyzing the political attention to the guiding idea of equivalent living conditions and spatial monitoring. Then we will analyze the topics of the Spatial Planning Report, which is the monitoring device used by the federal government in the area of spatial planning.

\subsection{Political attention to equivalent living conditions and the Spatial Planning Report}

We counted the documents of the German parliament mentioning 'equivalent living conditions' or the Spatial Planning Report to get a rough indication of the political attention paid to the idea of equivalent living conditions. Plotted across the election periods since the foundation of the Federal Republic of Germany (Fig. 1), the distribution of frequencies shows that there has been more explicit reference to the idea of equivalent conditions than to the Spatial Planning Report. In fact, the cycles of attention even seem to be fairly independent of one another. The change in attention paid to equivalent living conditions is most clearly visible in the plenary minutes (though this change is evident in the printed matter as well). There is a small peak in the 1970 s when the Federal Program of Spatial Planning of 1975 was debated. A second peak occurs after German unification, when economic differences between East and West Germany became a salient aspect. The largest peak of 
attention occurred in recent years, when an assumed relationship between regional disparities and more recent voter turnout for the neonationalist party Alternative für Deutschland (AfD) entered the public and official repertoires of interpretation $[10,82]$.

Compared to this wavelike development, the overall number of documents mentioning the Spatial Planning Report is obviously lower. There is a first wave of attention paid to the report right after its institutionalization in 1963, which declines in the late 1970s and early 1980s. From the early 1990s onwards, equivalent living conditions becomes an increasingly salient political issue. It seems that while political controversy has concentrated on the interpretation of the idea of equivalent living conditions, quantitative reporting on regional disparities has become taken for granted. How can we explain this apparent discrepancy between the political attention placed on a guiding idea of federal spatial planning and the policy instrument that is meant to monitor its implementation?

A potential answer to this question lies in the fact that Germany's federal spatial policy has mainly had a coordinating rather than an actually material character [81]. The limited power of federal spatial policy has been attributed, firstly, to the very limited ability of the state to govern the 'market forces' that determine the agglomeration process [83]. It has also been attributed to two main schisms in the German political system: Across levels of government, the German states have opposed a stronger role of the federal government because that would interfere with their own authorities over spatial planning. Within the federal government itself, other departments have fiercely held onto their competencies, making a more prominent role for spatial planning largely unviable [84]. With respect to both schisms, the interests of the actors outside of the policy field of spatial planning converge towards the aim of having federal legislation with few binding obligations $[65,84]$. As a consequence, "coordination by information" became a slogan that legitimized the regular provision of information on spatial developments as one of the main activities of federal spatial planning policy [18]. However, the potential effects of the provision of quantitative information should not be underestimated. With regard to the relationship between the German federal government and the states, it has been argued, for example, that transparency about the states' shares in the allocation of federal government funds tends to reinforce a schematic use of routinized allocation formulas across policy fields rather than more targeted allocation formulas that would be more susceptible to political appraisal and critique. Similarly, transparency about the significant differences in regional living conditions might give rise to new political claims for improved funding programs [84]. While these explanations apply to the relative weakness of federal spatial planning as a more general policy field, they fail to explain the varying amount of political attention paid to the issue of equivalent living conditions.

Next, we examined the Spatial Planning Report more closely in order to analyze the idea of equivalent living conditions as well as the topics of quantitative regional monitoring in which it has been embedded.

\subsection{Topics of the Spatial Planning Report and the limited formalization of equivalent living conditions}

The first Spatial Planning Report was issued in 1963 upon request of Germany's federal government even before the duty by the government to regularly publish it was codified in the Federal Spatial Planning Act of 1965. Since then, it has been published at fairly regular intervals and has typically consisted of a basic general structure that includes a description of more general societal trends, regional disparities, spatial policies and the coordination between relevant actors in this policy field. Until the 1990s the Spatial Planning Report was issued by the government ministry tasked with this responsibility. Since 2000 it has been authored by the federal research institute BBSR in order to increase the scientific independence of the report. The $2017 \mathrm{Re}$ port was the first to explicitly set a thematic focus for the entire report. Previous reports typically contained a broader outlook, including only a limited amount of thematically focused chapters.

\subsubsection{The use of the phrase 'equivalent living conditions'}

In order to trace the use of the phrase 'equivalent living conditions' in the Spatial Planning Report, we conducted semi-automated frequency counts of the phrase itself along with semantically related words that we identified manually when we analyzed the reports for other possible expressions with a similar meaning.

The frequency count in Fig. 2 shows that the phrase itself has become a relatively fixed expression within the report but it is far from being used as frequently as the two German terms that are usually translated as 'living conditions' (Lebensbedingungen, Lebensverhältnisse). The phrase 'equivalent living conditions' was used for the first time in 1974 when the Federal Program of Spa- 


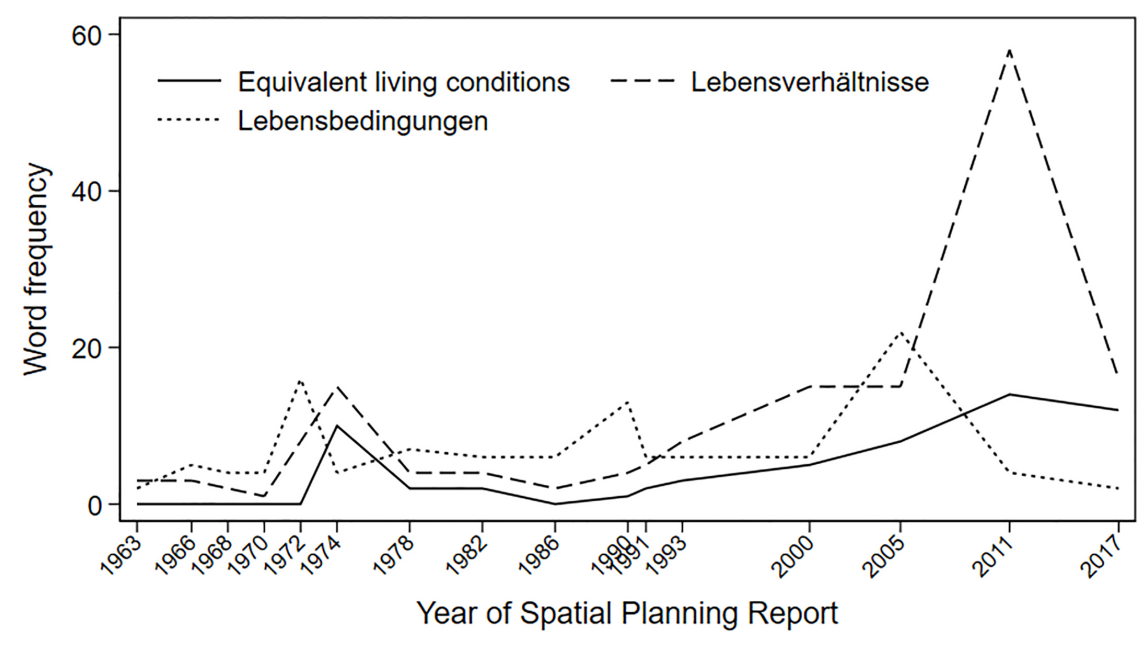

Fig. 2. Frequencies of the phrase 'equivalent living conditions' and related terms in Spatial Planning Reports (1963-2017).

tial Planning of 1975 was being prepared. The use of this phrase declined during the 1980 s, increasing again after 1990 and peaking in the report from 2011, which explicitly aimed at the operationalization of 'equivalent living conditions' [12]. While both German terms that translate to living conditions (Lebensbedingungen, Lebensverhältnisse) are used with similar frequencies during the period under analysis, the obvious exception is the report from 2011 (Fig. 2). By using this term, the text refers more directly to the phrase codified in the Basic Law and other legal sources [85], striving to legitimize this potentially controversial endeavor of quantification. Generally speaking, political attention towards the idea of equivalent living conditions is reflected with a similar basic tendency in the Spatial Planning Reports; however it is not as pronounced as in the documents issued by the German parliament. How do these cycles of attention relate to the topics of the report that we identified?

\subsubsection{Topics of the Spatial Planning Report}

The contents of the Spatial Planning Reports up to 2005 have previously been described by other authors, each identifying particular conflicting objectives reflected in the reports $[80,83,86]$. As early as 1976, it was observed that federal spatial planning faced the crucial dilemma of shifting scarce resources either towards fostering agglomeration and growth or towards slowing down deglomeration and outmigration from rural areas [83]. During the late 1990s this dilemma became a trilemma due to the global discourse on sustainable development [86]. A rather general feature of monitoring regional disparities is that such an endeavor typically implies a place-based framing of problems and related policies, whereas alternative person-oriented framings, implying a mobility of the population, are implicitly disregarded [80]. However, none of the former analyses of the Spatial Planning Report focused on the preconditions or consequences of quantification.

Our approach of using NMF topic models to analyze these documents differs in its innovative methodology and, in part, in the results yielded. Like other authors, we were able to identify topics that are specific to several of the Spatial Planning Reports but less so to others (Fig. 3). Unlike earlier analyses, our results pay closer attention to the diversity of the aspects within the topics identified. The five topics that we identified are each characterized by a constellation of particular words that occur with a relatively high overall frequency throughout the entire text corpus but which are also concentrated in particular documents (Table 2). Hence, words that only appear infrequently, or words that appear frequently but are distributed relatively equally across all texts, are less likely to be part of the topics identified by an NMF model. The words of a topic identified by the NMF algorithm are, at first glance, more heterogeneous than one would expect from a sequential reading of the texts. Nevertheless, the overall distribution of the topics across the documents we analyzed has proven to be fairly robust when different model specifications are used.

Against this backdrop, we labeled each identified topic with a term that seemed best suited to intuitively capturing its specificity so that it could be more easily identified throughout the rest of the paper. Furthermore, we used the periodization of Spatial Planning Reports suggested by the topic modeling in order to select those topics for an in-depth analysis for which our semi- 


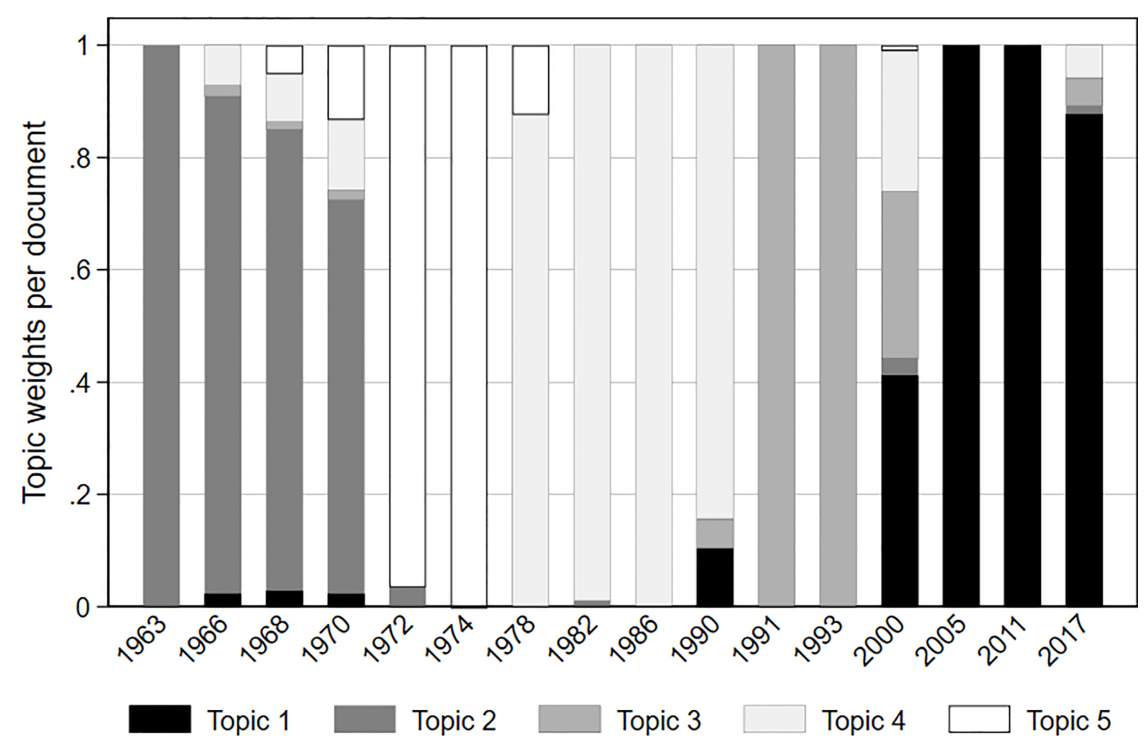

Fig. 3. Distribution of topics over Spatial Planning Reports (1963-2017).

automated frequency counts suggested a high prevalence of the idea of equivalent living conditions. The topics were identified by 139 words overall (Table 2 ). Topic 1 (32 words), which we labeled the Transnational Topic, clearly was the dominant topic in the reports for the years 2005, 2011, 2017 and to a lesser extent for 2000 as well. It also occurred in the reports from 1990 and 1966 to 1970 . Topic 2 (19 words), which we named the Subsidies Topic, dominated in the reports from 1963 to 1970 and occurred in 1972 as well. Topic 3 (24 words), which we called the Unification Topic, was the major topic of the reports for 1991 and 1993 and was also present in the 2000 report. Topic 4 (36 words), which we refer to as the Common Tasks Topic, was the most important topic in the years 1978 to 1990 but also occurred in 1966 to 1970 . Topic 5 (28 words), which we termed the Federal Spatial Planning Program Topic, was the most salient topic in the reports from 1972 and 1974, also appearing in adjacent years. Very few words appeared in more than one topic. Hence, according to the frequency distribution depicted in Fig. 2, the Transnational Topic (Topic 1) and the Federal Spatial Planning Program Topic (Topic 5) were found to be the most relevant for in-depth analysis.

Due to the increasing political attention the German parliament has paid to the issue of equivalent living conditions in recent years (Fig. 1) and the obvious relevance of Topic 1 in the Spatial Planning Reports issued from 2000 onwards (Fig. 3), we expected this term to be salient in Topic 1 . However, if we look at the 32 words constituting the Transnational Topic (Topic 1), the phrase 'equivalent living conditions' (recoded to a single word: gleichwertigelebensverhältnisse) is not among them. Nor is it part of one of the other four topics. Hence, the phrase we expected to be salient does not seem to occur in a similar configuration of words. Instead we are led to assume that the phrase has been used in very different thematic constellations across time. This suggestion can be substantiated if we concentrate on analyzing the nouns and named entities constituting the different topics [75] - Topic 1 and Topic 5 in particular. In the analysis, words in single quotation marks are listed in Table 2.

Subsidies (Topic 2): During the period of 1963 to 1970, when Topic 2 was dominant in the Spatial Planning report, the phrase 'equivalent living conditions' had not yet been coined. This did not occur until the early 1970s [79]. The coinage of a standard phrase is relevant to operationalization because indicators that are used systematically require clear labels in order to be able to announce what they measure. We refrain from a very detailed analysis of Topic 2 here; however, for the aspects examined by this paper, it is relevant to note that during this period there were three types of regions considered to be problematic and in need of political intervention or 'subsidies'. First, rural areas that faced depopulation due to a lack of job opportunities were categorized as regions lagging behind average development. Second, cities confronted with suburbanization were categorized as 'agglomeration zones' and measured as 'functional urban areas'. It was feared they would become overcrowded and overburdened. Third, 
'the zone bordering the GDR' was considered in need of special support because there were significantly fewer opportunities of spatial interconnectedness and, as a consequence, also fewer job opportunities due to the essentially impermeable border. According to the Treaty of Rome, which established the European Economic Community, national subsidies were only allowed under certain circumstances. In Germany, "the zone bordering the GDR" as well as "backward regions" were considered to meet the relevant criteria [26]. Problematizations of regional disparities focused on economic issues and had led to regional economic policy programs since the 1950s [87] - yet not explicitly under the label of equivalent living conditions.

Federal Spatial Planning Program (Topic 5): Topic 5 dominated in the reports from 1972 and 1974 but had also been around in previous years. These were the reports that prepared the 'Federal Program for Spatial Planning' which formally contained the phrase 'equivalent living conditions'. The program was intended to formulate concrete aims for the regional development of the national territory that were broader than those programs for regional economic policy already in existence. Two key instruments of regional economic policy had been created in 1969 in the form of the Common Task "Improvement of the Regional Economic Structure" and the Common Task "Improvement of Agricultural Structure and the Protection of Coasts". Both have been a joint responsibility of the federal government and the states.

The report from 1974 describes the creation of equivalent living conditions as a key objective of the federal government in addition to the aim of preserving natural resources [21]. The aim was concretized as a minimum supply of jobs, housing, and opportunities for education, recreation and communication across the national territory. Equal opportunities for all citizens were to be improved by providing comparable material conditions within a reasonable distance. That would require political decisions on a) criteria for quantities and qualities of facilities, b) the spatial units for which these criteria would apply, and c) the actual allocation of facilities. With regard to such criteria, the report recommended minimum standards that would correspond to the conditions enjoyed by half of the population in more densely populated areas. This orientation towards a minimum standard based on the median of more densely populated areas shows that the issue was about raising standards of living [85]. Spatial scales for these standards should be adapted to the catchment areas of the service in question, which meant that functional areas were preferred over administrative units. Equivalent living conditions were to be achieved by a system of developmental centers and 'developmental axes' connecting them [21]. The analytical base for this developmental concept is the theory of central places [88]. In German federalism, the states assign centrality functions of three to four orders to particular cities and towns, creating a pattern of relative decentral provision of local public services. The 1972 report had already identified 38 territorial units that were comprised of a center of first order and its hinterland which had at least 400,000 inhabitants. The borders of these units were typically made up of several counties [22]. A central task of the federal regional policy was to coordinate the financial means invested by the federal government departments in a spatial perspective based on these territorial units.

Furthermore, within the context of the idea of equivalent living conditions, matters of environmental protection became more relevant in the Spatial Planning Report. Although the report from 1963 did devote a small chapter to the economic strain on natural resources, the salience of this issue increased in the 1970s. The word with the highest weight in Topic 5 was "carrying capacity' which refers to the robustness or resilience of natural spaces in the face of growing stress over soil, water, air and vegetation resulting from the extension of economic activities, in particular settlement construction, mining, tourism, waste production and noise [24]. On the one hand, reasonable thresholds for the limitation of externalities from production and consumption were to be identified; on the other hand, certain landscapes were to be protected from these externalities.

Topic 5 also lists several actors that have played a role in territorial governance. One key actor is the 'Main Commission' of the Conference of Ministers for Spatial Planning (MKRO), which was institutionalized in 1967 as a forum of cooperation between the federal government and the states. Other actors listed in Topic 5 are government units of the states which issue legal regulations relevant for spatial planning. Today the MKRO is made up of 16 state ministers and the federal minister responsible for spatial planning. The fact that this responsibility has changed several times underscores the rather marginal position of this policy field among the federal departments. The rules of the MKRO specify that every member has one vote and decisions are passed with a simple majority. This gives the federal government a moderating role with no veto rights. It also has limited authority to pass detailed legislation in this policy field, which had been exclusively under state jurisdiction up until 2006. Although this has been 
formally changed, it has yet to have many practical consequences [89].

Common Tasks (Topic 4): Originally projected for the period up to 1985 , the report issued in 1978 was already skeptical about the achievement of the aims set by the Federal Program for Spatial Planning. At the same time, the report pointed out that the social and economic environment of federal spatial planning had changed, which required some reorientation: First, there had been an improvement in the level of infrastructure supply in backward regions. Second, economic investment had declined which was interpreted as a need to put special emphasis on the creation of jobs - not only in rural areas but also in traditional industrial regions hit by the structural change in the economy. Third, declining birthrates were expected to require new forms of organization for infrastructure supply in sparsely populated areas [20]. As a consequence of the assumed convergence of regional living conditions and the new emphasis on economic development, there was a decline in salience of the notion of equivalent living conditions up until the 1990 report.

In terms of measuring equivalent living conditions, it should be noted that the definition of the 38 territorial units for federal spatial policy was met with criticism. The 1978 report admitted that these units were too large to enable the identification of meaningful regional disparities [20]. Furthermore, the departmental planning units in the federal ministries used different territorial units for their own planning purposes, which made coordination between spatial planning and functional planning difficult. Therefore, the report proposed harmonizing spatial planning units especially with respect to the planning regions used in traffic planning and with the labor market regions used in the 'Common Task' of regional economic policy salient in Topic 4.

Unification (Topic 3): The reports published in 1991 and 1993 are clearly marked by Topic 3 , which underlines different issues that become salient as a consequence of German reunification. The incorporation of the territory of the former German Democratic Republic (GDR) led to the perception that a diverse range of infrastructure in the eastern part of unified Germany was perceived as being in 'decay' and in need of modernization: 'sewage', 'industrial housing', 'telecommunication' and much more. Unemployment rocketed due to the insolvency of many formerly state-owned companies that were not able to survive in an increasingly global capitalist environment. The key actor in the process of privatizing public enterprises after the end of the GDR was the 'Treuhandanstalt'. Rising unemployment and the difficulty for young cohorts to enter the labor market prompted the 'employment agency' to intervene and provide benefits to 'short time workers' who were in danger of losing their jobs, as well as financing measures 'in preparation of taking up a vocational occupation'. At the same time, a wave of suburbanization produced many 'newly built housing areas', because access to privately owned single-family houses had been very limited during communism. Although the sudden increase in regional disparities was an obvious issue during these years, their problematization in terms of the idea of equivalent living conditions only developed slowly.

Transnational Topic (Topic 1): Since the turn of the millennium there has been debate about what should count as equivalent from a regional perspective. In fact, the idea of equivalence has been interpreted by experts in contradictory ways [79]: At one end of the spectrum is the claim that the constitutional principle is meant to be a spatial expression of the welfare state, aiming to provide territorial equalization policies [90]. At the other end of the spectrum is the position that 'equivalent' should not be misinterpreted as 'equal' but lead to a valuation of spatial differences [91,92]. From 1949 to 1994 Art. 72 of the Basic Law even contained the formulation of 'uniform living conditions' (Einheitlichkeit der Lebensverhältnisse) until it was changed to the phrase 'equivalent living conditions'. Article 72 of the Basic Law regulates the legislative competence of the central state and the federal states and now grants the national legislature the right to issue laws that could overrule state laws if the equivalence of living conditions within the national territory is at risk. However the competence of competing legislation at the federal level came at the price of replacing a strong notion of equality with the more ambiguous phrase of equivalent living conditions [85].

In order to trace this controversy in the Spatial Planning Report, we conducted frequency counts of nine nouns and adjectives that are typically used in the description and evaluation of regional living conditions (Fig. 4). Their use in the Spatial Planning Report is remarkable in several respects. First, 'uniformity' and 'uniform' (Einheitlichkeit, einheitlich), the modifiers that had been used in the Basic Law from 1949 to 1994 to evaluate living conditions have never occurred much in the Spatial Planning Report even though it was juridically more precise than the current phrase. Instead, the language of the planning report has always been more oriented towards the notion of 'equivalence'. Second, the term 'equivalence' is sometimes used in the report 


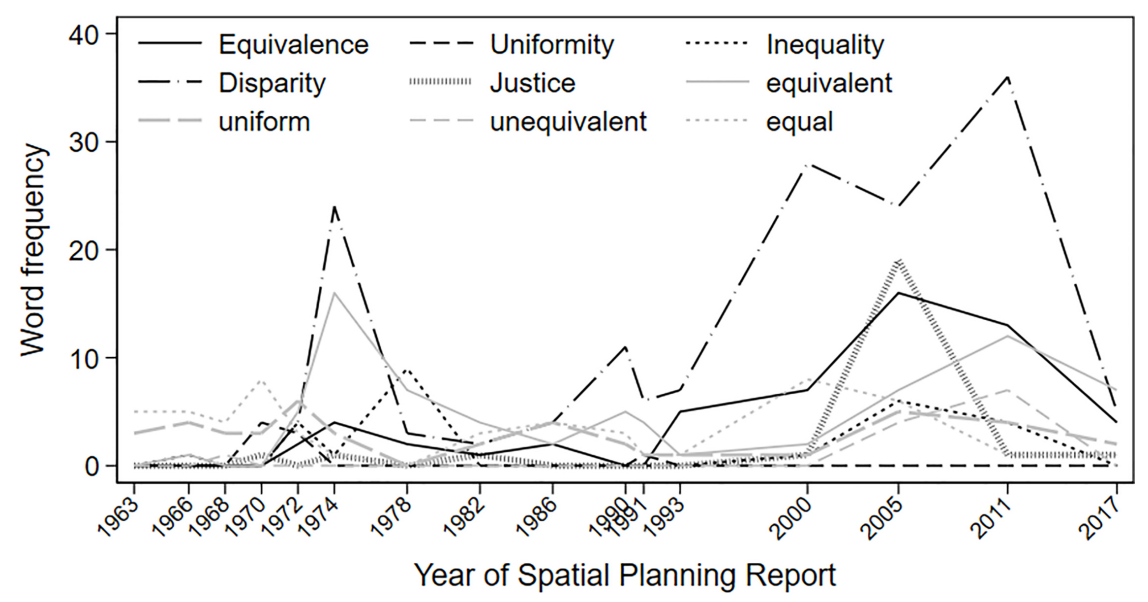

Fig. 4. Evaluative words typically used to describe regional disparities.

as an abbreviation of the phrase equivalent living conditions, which indicates to us that the evaluative part is the crucial aspect of the idea. Such condensing of meaning into one single word might even be prerequisite before an idea can become politically more influential. The use of 'equivalence' peaked in the report from 2005, where it was interpreted as a national expression of the global concern for spatial justice. The latter entered the report as one of three dimensions of the notion 'sustainable development' [13]. The term 'justice' is not used frequently in the Spatial Planning Report except for in that one report. Third, the word 'disparity' is used much more frequently than 'inequality' in order to describe spatial distributions. This is probably due to the fact that, among the modifiers analyzed, it is usually perceived to be the most neutral one. In contrast to using 'inequality' in the interpretation of indicators, 'disparity' suggests a weaker normative reading. Hence, its frequent use can be interpreted as a strategy to increase the epistemic authority of the report and to leave normative questions to policymakers. Interestingly its use increases from 2000 onwards when responsibility for the report was taken over from the federal ministry by the federal spatial research institute BBSR.

The Spatial Planning Report from 2000 argues that the increase in the range of regional disparities following the German unification has made the idea of equivalent living conditions once again politically relevant. Indeed, Topic 1 contains several cues in this regard. First, the word 'aging' is the term with the highest weight in this topic and second, several named entities (cities and states) are listed that are located in the eastern part of Germany. Another element is the adjective 'eastern German'. Indeed, a declining birthrate and outmigration hit the eastern part of Germany hard as was the case in most formerly communist states. Uncertainty about the future caused delays in decisions to have children and, faced with a lack of job opportunities, many young and well-qualified people emigrated to the western part of Germany. Declining population numbers made it increasingly expensive for the public sector to provide technical and social infrastructures which became ever more oversized in many places [93]. Cutbacks and school closures, for example, were the frequent responses by policymakers in shrinking regions, especially in the eastern part of Germany.

However shrinking regions coexist with urban growth areas. In growing monocentric regions with rising housing prices, suburbanization processes have continued and have led to a further increase in average 'commuting distances'. While suburban areas have long been a concern for spatial planning, an aging population presents a new facet. The young families that once moved to these areas very often became emptynest households when their children moved out. This age structure needs special attention when it comes to elderly-care planning.

But aging and suburbanization are just two of the 'challenges' that Topic 1 identifies in the Spatial Planning Report (Table 2). Indeed, the notion of 'challenges' is part of a mobilizing vocabulary that first entered the documents under analysis in 1990 and is used more frequently from 2000 onwards. A similar vocabulary can be found in European regional development programs [68]. If we take into account that this is the period when the spatial planning office BBSR took over responsibility for the Spatial Planning Report from the federal ministry, it can be interpreted as an activating form of problematization addressed at policymakers. Furthermore, the fact that 'challenges' appears in the 
plural indicates a perception of complexity in Topic 1 that is not present in the topics dominating former periods. Very often descriptions and interpretations in the period 2000-2017 bear a reference to a particular 'context' that is relevant, indicating a differentiation of problem descriptions. Furthermore, the frequent use of 'scenario' shows a high awareness for the contingency of policy decisions.

A great deal of this new complexity and awareness of uncertainty stems from different 'transnational' processes: European integration not only brought about the introduction of the 'euro' in 1999, but also the European Spatial Development Perspective (ESDP), agreed on by the ministers responsible for spatial planning at the Informal Council in Potsdam. As the consequence, attention was paid for the first time to 'metropolitan regions' and 'metropolitan functions' in the Spatial Planning Report of 2000. The ESDP envisaged metropolitan regions as nodes that connected Europe to other continents and increased its global competitiveness. Since spatial development concepts in Germany always struggled with a tension between economic growth and regional equalization, the idea of developing metropolitan regions and their interconnectedness increased this tension. It added another layer to the traditional German hierarchy of central places. 'Community initiatives' were an important part of the ESDP. One example was 'INTERREG', a program designed to contribute to the objectives of structural policy by funding integrative territorial development projects that had existed since 1989 . With a view of further enlarging the European Union, the European Commission also announced an economization of the programs for structural development policy in 1999. First, it proposed reducing the maximum share of population in funded regions of member states as well as the number of community initiatives [14]. Another transnational process co-constructed in the Spatial Planning Report was the global discourse on 'sustainable' development as objectified for example in the action plan 'Agenda 21' of the United Nations in 1992. The report reflects the translation of this global discourse into regional and local processes, identifying indicators for measuring progress towards sustainable development. Within this discourse, rural areas acquire new functions as 'cultural landscapes' and 'open spaces' that have to be protected against destructive impacts e.g. economic activities. At the same time, their possible contribution to economic activities is reframed as locations for "wind power plants', a source of renewable energy. As part of Germany's engagement with the Agenda 21 process, the Spatial Planning Act was reformed in 1998 and the guiding idea of equivalent living conditions became embedded in a 'paradigm of sustainability' [14]. This catalyzed the first attempt to operationalize the idea of equivalent living conditions in the 2005 report [13].

\subsubsection{Measuring equivalent living conditions and the competition between instruments}

Several decisions need to be made in order to measure equivalent living conditions. From a methodological perspective, it has to be decided which dimensions are relevant, which indicators to use, which (spatial) units to observe and if cross-sectional or longitudinal observations are preferable. From a political perspective, a measure for the normative evaluation of living conditions, a target, a target value or a threshold has to be defined. What counts as equivalent? Should compensation between dimensions be allowed or not? Among the documents analyzed, the Spatial Planning Reports from 2005 and 2011 provide suggestions for an operationalization of equivalent living conditions and pick up potentially contentious aspects of - at first glance purely methodological decisions.

The report from 2005 presents an operationalization of social and spatial justice as part of a national contribution to the global Agenda 21 process [13]. In this report, equivalent living conditions are equated with social and spatial justice and become one of three potentially conflicting dimensions in the concept of sustainable development. The other two are economic competitiveness and environmental protection. Sustainable development is operationalized using 17 "key indicators" [13], nine of which represent the subdimensions of social and spatial justice (Table 1). The selection of these indicators is briefly made plausible, however the choices are presented as more obvious than contingent. The brevity in justifying the decisions made might be due to the fact that the indicator concept had already been presented to a meeting of the United Nations and was an updated version [13].

Subdimensions of social and spatial justice were conceptualized as non-substitutable and each subdimension was measured by one indicator. Target values were meant to represent a minimum standard to be reached; otherwise there was an indication of a deficit in social and spatial justice or a lack of equivalence of living conditions. Target values were set as percentages of national averages with the exception of housing supply, which was compared to the average for the type of region based on the settlement structure. Calculations were made on the BBSR's scale of 92 spatial planning units which typically comprise several counties. The 
Table 1

Suggested operationalizations of 'equivalent living conditions' in Spatial Planning Reports

\begin{tabular}{|c|c|c|c|}
\hline Year & Subdimensions & Indicators & Evaluation of equivalence \\
\hline \multirow[t]{9}{*}{2005} & Market income & 9 & Subdimensions non-substitutable \\
\hline & Transfer income & & One indicator per subdimension \\
\hline & Work participation & & Target values set as percentage of national average \\
\hline & Work participation of women & & Standardization of data for their target values \\
\hline & Unemployment & & (target value is 100 , range $0-200$ ) \\
\hline & Educational opportunities & & Average deficit of indicators with a deficit \\
\hline & Integration of migrants & & Spatial scale: BBSR spatial planning regions \\
\hline & Supply of housing & & \\
\hline & Local government debt & & \\
\hline \multirow[t]{6}{*}{2011} & Demography & 23 & Subdimensions non-substitutable \\
\hline & Economy & & Additive indices per subdimension \\
\hline & Labor market & & Z-transformed values \\
\hline & Wealth & & Equal weighting, except unemployment rate and GDP per employed person (double \\
\hline & Infrastructure & & weighting) \\
\hline & Housing market & & $\begin{array}{l}\text { Deviation from national average by more than a standard deviation as a benchmark } \\
\text { Spatial scale: districts. }\end{array}$ \\
\hline
\end{tabular}

definition of these target values was, in part, justified by reference to other conventions that had been defined politically e.g. the $75 \%$ threshold used to demarcate the EU assisted areas. Others were set without explicit reference to existing conventions, a procedure that was admittedly "imperfect but necessary", having been practiced since the 1970s [13]. In 1976, shortly after the Federal Spatial Planning Program had been put in place, the Council for Spatial Planning (Beirat für Raumordnung), an advisory body of scientists and interest groups at the federal ministry, recommended the most extensive catalog of indicators and minimum standards for the entire national territory as a basis for political discussions. It contained a total of 167 indicators in six dimensions and 67 subdimensions [94]. Data in the report from 2005 was normalized in order to be able to compare indicators of different subdimensions. Indicators with a deficit over the target value were used for calculating an average regional deficit. Cross-sectional data was used to assess regional disparities at one point in time, as well as the development of these disparities over a period of five years. The magnitude of disparities was measured by the coefficient of variation and by counting the regions with a deficit. In 2001, between 9 and 41 regions exhibited a deficit in one of the assessed subdimensions of justice.

The report from 2011 operationalized equivalent living conditions using six subdimensions and 23 indicators, which were measured on the county level. Dimensions were presented as rather obvious; indicators were made plausible, for example, with regard to their practical relevance for political decision making. The subdimensions were conceptualized as non-substitutable; an additive index was constructed for each subdimension, which meant that the values of individual indi- cators could compensate each other. The construction of these additive indices was made possible by a Ztransformation of the data. Individual indicators entered the equation with equal weight, except for the GDP per employed person in the subdimension 'economy', and unemployment rate in the subdimension 'labor market' which were double weighted. The report interpreted the idea of equivalent living conditions as aiming to provide minimum standards across the national territory, an interpretation that is in line with the extensive recommendation of unitary indicators and thresholds by the Council for Spatial Planning from 1976. At the same time, the report quotes a more recent statement by the Council for Spatial Planning, which argued against uniform standards across the national territory and for spatially differentiated standards. On the one hand, it can be assumed that this argument reflects the academic criticism, which bemoaned the fact that quantitative indicators might have different meanings depending on the regional context in question $[95,96]$. On the other hand, it reflects the fact that, in German federalism, the states, not the federal government, are responsible for spatial planning and hence for the definition of standards in the first place. The federal government should only intervene if equivalence across the national territory is at stake. Yet, without a unitary national benchmark, it is not possible to evaluate that question because normative standards vary considerably across states. As a consequence, the Spatial Planning Report used the federal average as a benchmark and defined deviations larger than one standard deviation from the average as 'strongly below average'. An accumulation of 'strong deviations below average' were considered to represent unequivalent living conditions [12]. The report identified 21 counties with living conditions 'very strongly 
below average' (at least in four of the six dimensions), all of which were located in the eastern part of Germany. It further identified 20 counties with living conditions 'strongly below average' (in at least three dimensions and above average in a maximum of two dimensions). Fifteen of these counties were located in the eastern part of Germany and five in the western part.

When we compare the two operationalizations of equivalent living conditions briefly presented here, it becomes clear that there is a relatively stable consensus that economic development and participation in the labor market are crucial dimensions of this concept. Furthermore, the approach from 2005 is clearer in the sense that possible tensions between the dimensions of economic growth and justice are explicitly highlighted in the report. At the same time, a policy instrument for monitoring and supporting economic development already existed in Germany, namely the Common Task targeting regional economic development. This means that there would have been a certain redundancy in monitoring and, consequently, in intervening. Against the backdrop of possible competition between the instruments of regional economic policy and a potential instrument targeting equivalent living conditions, the report from 2017 focused on the theme of safeguarding the provision of material and organizational infrastructure (Daseinsvorsorge sichern). This report was the first to officially choose a particular theme for the entire report. It referred to the idea of equivalent living conditions (Fig. 2), yet not to the operationalizations proposed in the reports from 2005 and 2011. The report analyzed possible strategies for safeguarding the provision of material and organizational infrastructure across the national territory, a particular challenge in depopulating areas. Hence it explicitly carved out a narrower policy focus than the measurement concepts presented in earlier reports that spanned several dimensions of living conditions. Moreover, compared to the early 1970s, a recent discussion on equivalent living conditions has focused on how to keep from falling below a certain threshold instead of on increasing minimum standards [85]. A less encompassing thematic focus and a lower aspiration level might enhance the prospects for formalizing the idea of equivalent living conditions in a unitary way. Although a political think tank has proposed the creation of a Common Task ' $D a$ seinsvorsorge' [97], a program for which there would be shared federal and state responsibility, no such plans by relevant state actors have been announced.

One requirement of a unitary operationalization of equivalent living conditions would be a consensus on a relevant set of indicators among the crucial actors of German spatial planning policy, most notably the policy makers in the MKRO [96]. A step in this direction was made by an article that extensively sought to justify the setting of target values by referring to existing (politically decided) conventions in different policy fields [98]. Additionally, the federal government used the measurement concept from 2011 in order to answer a so-called small request in the German parliament about how many "left-behind regions" there were in Germany [10]. However, the measurement suggestions proposed so far were not picked up by the federal Equivalent Living Conditions Commission. Yet, the commission explicitly supported a current initiative of the BBSR to develop a measurement concept of equivalent living conditions that should be used for regular monitoring. That initiative has been explicitly designed as a "model project", integrating experts and local politicians [40]. The commission further stipulated that subjective indicators for life satisfaction should be analyzed with respect to their (causal) relevance for outmigration as part of this monitoring [99].

\subsubsection{Changing actor constellations and the localization of problems}

During the period under analysis, informal indicator use for representing the idea of equivalent living conditions in the Spatial Planning Report has shifted from analytical spatial categories towards a more individualized representation of territories. While this representational change still supports a place-based framing of problems, it does not facilitate collective action to cope with those problems. In order to substantiate our argument, we specifically compare the two topics that dominate those periods in which the idea of equivalent living conditions is most salient: Topic 1 (2000-2017) and Topic 5 (1972-1974). We focus on the constellation of actors and on the localization of problems in both topics.

From the description above, it has become clear that Topic 5, the Federal Spatial Planning Program Topic, is mainly populated by national actors and their instruments. The main issue of national actors and their confidence in the standardizing power of measurement and rational policymaking in the early 1970s was how to raise living standards, especially in regions classified as 'backward' [85,94]. One exception to the national constellation of actors in Topic 5 is the projections of the agricultural land needed to self-sufficiently feed the German population. These projections, made by the Organization of Economic Cooperation and Development 


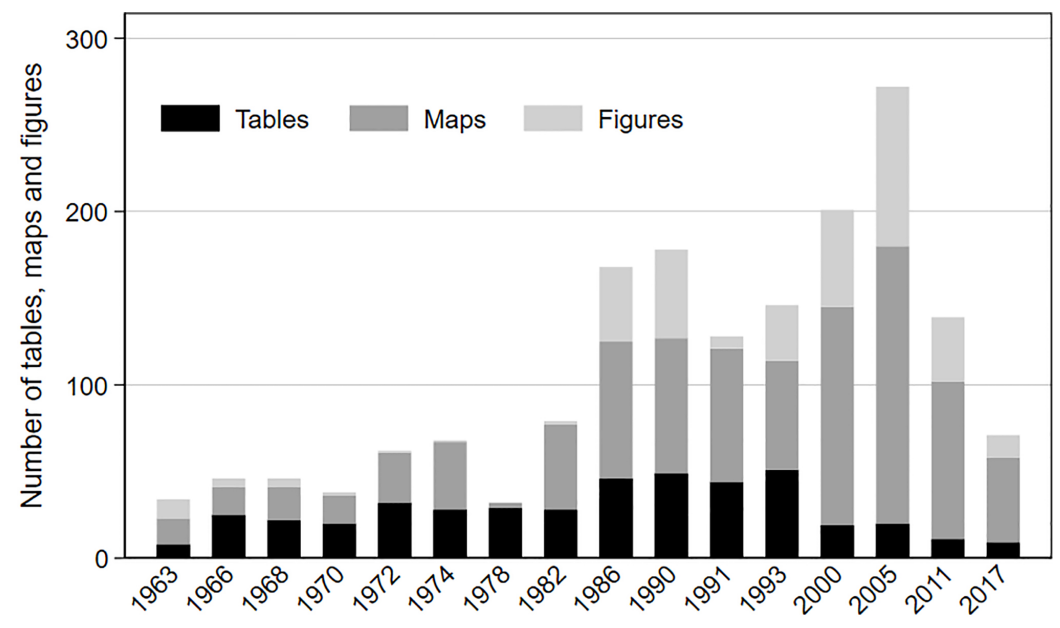

Fig. 5. Number of figures, maps and tables per Spatial Planning Report (1963-2017).

as well as individual scientists like George E. 'Rossmiller' from 'Michigan' State University, are intensely discussed in the report from 1972 (Table 2). They were used to estimate (make a 'prognosis' on) how utilization conflicts between settlement areas and different forms of open space usage could be ameliorated in the face of rising productivity in agriculture. Furthermore, matters pertaining to international relations and cooperation have been a regular part of all the reports since the very beginning.

Nevertheless, the salience of international actors, primarily the European Union and the United Nations, and their instruments in the more recent Transnational Topic (Topic 1) is striking. In this respect, the operationalization of the concept of sustainable development catalyzed attempts to formalize the idea of equivalent living conditions [13]. How about national actors? National actors are mentioned in the Transnational Topic, however their relative importance has declined relative to the Federal Spatial Planning Program Topic. A significant number of national actors in the Transnational Topic consists of the names of individual cities and states. While the names of cities and states can be interpreted as representing political actors, they are also a way to localize problems, especially on maps. The Transnational Topic names 8 political territories and 5 analytical spatial categories, whereas the Federal Spatial Planning Program Topic names 2 political territories and 4 analytical spatial categories. This individualizing way of localizing problems presents an alternative to the construction of analytical spatial categories. While the latter would be compatible with the formal establishment of intervention programs, the former is rather compatible with more informal and participatory ways of intervention, such as the 'model projects' that have existed in federal spatial planning since the late 1990s [11]. In addition to this, individualizing forms of localizing problems responsibilize local or regional actors rather than national ones.

Since the mid-1990s, depopulation, aging and problems related to spatial planning, such as school closures, have mainly occurred - though not exclusively in the eastern part of Germany. In the analyzed reports, this localization is increasingly indicated through an individualizing representation of space (names of cities and states) instead of through analytical categories that could be connected more clearly to a need for (federal) intervention. While the report from 2005, for example, partially categorized metropolitan regions, suburban areas and rural areas in a quantified way as 'spaces with a need for intervention', the definition of these spaces was not related to the operationalization of equivalent living conditions in the same report [13].

Why do we see this individualizing shift in the representation of space? In the first place, it seems to be the result of a change in the way quantitative results are presented to policymakers and the wider public in the Spatial Planning Report (Fig. 5). Simultaneously, it has the - probably unintended - consequences of mobilizing the individual agency of local governments while hampering the formation of space-based interest groups. Roughly speaking, the number of tables, maps and figures (graphs) - illustrative techniques that are typically used to highlight results - increased quite steadily during the period under observation up until 2005, at which point they declined. The report from 1978 is an exception because it contained an extensive annex that has not been published in a digital format. 
Table 2

Words and their frequency weights by topic (NMF model with a 'sentence' length of 40 words)

\begin{tabular}{|c|c|c|c|c|c|c|}
\hline Nr. & Words identified by the NMF model & Translation & $\begin{array}{c}\text { Frequency } \\
\text { weight }\end{array}$ & Topic & $\begin{array}{l}\text { Named spatial } \\
\text { entities }\end{array}$ & $\begin{array}{c}\text { Spatial } \\
\text { categories }\end{array}$ \\
\hline & \multicolumn{5}{|c|}{ Topic 1: Transnational (mainly 2005-2017) } & \\
\hline 1 & Alterung & Aging & 0.02849 & 1 & & \\
\hline 2 & Kulturlandschaften & Cultural landscape & 0.02022 & 1 & & 1 \\
\hline 3 & Interreg & $\begin{array}{l}\text { INTERREG [funding program of } \\
\text { the EU for projects of territorial co- } \\
\text { operation] }\end{array}$ & 0.01912 & 1 & & \\
\hline 4 & Kontext & Context & 0.01637 & 1 & & \\
\hline 5 & Freiraum & Open space & 0.01612 & 1 & & 1 \\
\hline 6 & Metropolregionen & Metropolitan regions & 0.01462 & 1 & & 1 \\
\hline 7 & Metropolfunktionen & Metropolitan functions & 0.01222 & 1 & & \\
\hline 8 & Union [Europäische Union] & union [typically: European Union] & 0.01174 & 1 & & \\
\hline 9 & Potsdam & Potsdam & 0.01135 & 1 & 1 & \\
\hline 10 & Dresden & Dresden & 0.01135 & 1 & 1 & \\
\hline 11 & Bundesausbaugebiete & Federal investment areas & 0.01116 & 1 & & 1 \\
\hline 12 & Windenergieanlagen & Wind power plants & 0.01075 & 1 & & \\
\hline 13 & Nachhaltigen & Sustainable & 0.01014 & 1 & & \\
\hline 14 & Erfurt & Erfurt & 0.00989 & 1 & 1 & \\
\hline 15 & Szenario & Scenario & 0.00944 & 1 & & \\
\hline 16 & Ostdeutsche & East German & 0.00926 & 1 & 1 & \\
\hline 17 & Sachsen & Saxony & 0.00655 & 1 & 1 & \\
\hline 18 & Sachsenanhalt & Saxony-Anhalt & 0.00608 & 1 & 1 & \\
\hline 19 & Vernetzung & Interconnectedness & 0.00595 & 1 & & \\
\hline 20 & Gemeinschaftsinitiative & Community initiative & 0.00575 & 1 & & \\
\hline 21 & Netzwerke & Networks & 0.00501 & 1 & & \\
\hline 22 & $\begin{array}{l}\text { Eurek [Europäisches Raumentwick- } \\
\text { lungskonzept] }\end{array}$ & $\begin{array}{l}\text { European Spatial Development } \\
\text { Perspective (ESDP) }\end{array}$ & 0.00443 & 1 & & \\
\hline 23 & Leipzig & Leipzig & 0.00378 & 1 & 1 & \\
\hline 24 & Pendeldistanzen & Commuting distances & 0.00360 & 1 & & \\
\hline 25 & Mecklenburgvorpommern & Mecklenburg western pomerania & 0.00359 & 1 & 1 & \\
\hline 26 & Politiken & Politics & 0.00327 & 1 & & \\
\hline 27 & Herausforderungen & Challenges & 0.00319 & 1 & & \\
\hline 28 & Transnationale & Transnational & 0.00293 & 1 & & \\
\hline 29 & Agenda [typically Agenda 21] & Agenda & 0.00258 & 1 & & \\
\hline 30 & Suburbanen & Suburban & 0.00241 & 1 & & 1 \\
\hline 31 & Infrastrukturen & Infrastructures & 0.00004 & 1 & & \\
\hline \multirow[t]{3}{*}{32} & Euro & Euro & 0.00003 & 1 & & \\
\hline & Total & & & & 8 & 5 \\
\hline & \multicolumn{4}{|c|}{ Topic 2: Subsidies (mainly 1963-1970) } & & \\
\hline 1 & Stadtregionen & Functional urban areas & 0.04113 & 2 & & 1 \\
\hline 2 & Elektrifizierung & Electrification & 0.02042 & 2 & & \\
\hline 3 & Abfallstoffe & Waste materials & 0.01985 & 2 & & \\
\hline 4 & Beihilfen & Subsidies & 0.01894 & 2 & & \\
\hline 5 & Verkehrsdichte & Traffic density & 0.01548 & 2 & & \\
\hline 6 & Mehrgemeindliche & $\begin{array}{l}\text { Consisting of more than one } \\
\text { municipality }\end{array}$ & 0.01290 & 2 & & \\
\hline 7 & Beanspruchung & Stress & 0.00841 & 2 & & \\
\hline 8 & Kubikmeter & Cubic meter & 0.00736 & 2 & & \\
\hline 9 & $\begin{array}{l}\text { Bavav [Bundesanstalt für Arbeitsver- } \\
\text { mittlung und Arbeitslosenversicher- } \\
\text { ung] }\end{array}$ & $\begin{array}{l}\text { Federal Agency for Employment } \\
\text { and Unemployment Insurance }\end{array}$ & 0.00655 & 2 & & \\
\hline 10 & Ballungszonen & Agglomeration zones & 0.00588 & 2 & & 1 \\
\hline 11 & Kreisen & Counties & 0.00583 & 2 & & 1 \\
\hline 12 & Standortsituationen & Location situations & 0.00559 & 2 & & \\
\hline 13 & Teiles & Part & 0.00549 & 2 & & \\
\hline 14 & Haushaltsjahr & Budget year & 0.00498 & 2 & & \\
\hline 15 & Unternehmer & Entrepreneur & 0.00449 & 2 & & \\
\hline 16 & Zonenrandgebiet & Zone bordering the GDR & 0.00442 & 2 & & 1 \\
\hline
\end{tabular}


Table 2, continued

\begin{tabular}{|c|c|c|c|c|c|c|}
\hline Nr. & Words identified by the NMF model & Translation & $\begin{array}{l}\text { Frequency } \\
\text { weight }\end{array}$ & Topic & $\begin{array}{l}\text { Named spatial } \\
\text { entities }\end{array}$ & $\begin{array}{c}\text { Spatial } \\
\text { categories }\end{array}$ \\
\hline 17 & Hebung & Lifting & 0.00369 & 2 & & \\
\hline 8 & Industrieberichterstattung & Industrial reporting & 0.00340 & 2 & & \\
\hline \multirow[t]{3}{*}{19} & Wohnungsbaues & Housing construction & 0.00168 & 2 & & \\
\hline & Total & & & & 0 & 4 \\
\hline & \multicolumn{4}{|c|}{ Topic 3: Unification (mainly 1991-2000) } & & \\
\hline 1 & Stov [Standortverwaltung] & Administration of a military base & 0.02954 & 3 & & \\
\hline 2 & Abwasserinfrastruktur & Sewage infrastructure & 0.02376 & 3 & & \\
\hline 3 & Plattenbauweise & Industrial housing construction & 0.02252 & 3 & & \\
\hline 4 & Investitionspauschale & Flat-rate investment & 0.01881 & 3 & & \\
\hline 5 & Tierproduktion & Animal production & 0.01858 & 3 & & \\
\hline 6 & Raumordnungsverfahrens & Spatial planning procedure & 0.01633 & 3 & & \\
\hline 7 & Berufsvorbereitenden [Maßnahmen] & $\begin{array}{l}\text { [measures] in preparation for taking } \\
\text { up a vocational occupation }\end{array}$ & 0.01334 & 3 & & \\
\hline 8 & Neubausiedlungen & Newly built housing areas & 0.01334 & 3 & & \\
\hline 9 & Umweltrahmengesetz & Environmental Framing Act & 0.01334 & 3 & & \\
\hline 10 & Csfr & $\begin{array}{l}\text { Czech and Slovak Federative Repub- } \\
\text { lic }\end{array}$ & 0.01177 & 3 & 1 & \\
\hline 11 & Sachsenanhalt & Saxony-Anhalt & 0.01091 & 3 & 1 & \\
\hline 12 & Telekommunikationsinfrastruktur & Telecommunication infrastructure & 0.01086 & 3 & & \\
\hline 13 & Arbeitsverwaltung & Employment agency & 0.00991 & 3 & & \\
\hline 14 & Ostteil & Eastern part & 0.00954 & 3 & & \\
\hline 15 & Leipzig & Leipzig & 0.00762 & 3 & 1 & \\
\hline 16 & Rauchgasreinigung & Flue gas cleaning & 0.00630 & 3 & & \\
\hline 17 & Kurzarbeiter & Short-time workers & 0.00131 & 3 & & \\
\hline 18 & Reichsbahn & $\begin{array}{l}\text { German Reich Railways, the state- } \\
\text { owned railways of the GDR }\end{array}$ & 0.00127 & 3 & & \\
\hline 19 & Verfall & Decay & 0.00120 & 3 & & \\
\hline 20 & Ansprechpartner & Contact person & 0.00100 & 3 & & \\
\hline 21 & Heizungsanlagen & Heating installation & 0.00058 & 3 & & \\
\hline 22 & Treuhandanstalt & $\begin{array}{l}\text { Agency responsible for the privatiza- } \\
\text { tion of public enterprises after the end } \\
\text { of the GDR }\end{array}$ & 0.00040 & 3 & & \\
\hline 23 & Havel & Havel & 0.00002 & 3 & 1 & \\
\hline \multirow[t]{3}{*}{24} & Magdeburg & Magdeburg & 0.00000 & 3 & 1 & \\
\hline & \multirow{2}{*}{\multicolumn{4}{|c|}{ Topic 4: Common tasks (mainly 1978-1990) }} & 5 & 0 \\
\hline & & & & & & \\
\hline 1 & Euskirchen & Euskirchen & 0.03355 & 4 & 1 & \\
\hline 2 & Zonenrandgebiet & Zone bordering the GDR & 0.02830 & 4 & & 1 \\
\hline 3 & Finanzleistungen & Financial benefits & 0.01609 & 4 & & \\
\hline 4 & Verdichtungsschwerpunkte & Focal points of agglomeration & 0.01503 & 4 & & 1 \\
\hline 5 & Bietingen & Bietingen & 0.01262 & 4 & 1 & \\
\hline 6 & Hannover & Hannover & 0.01236 & 4 & 1 & \\
\hline 7 & Rheinlandpfalz & Rhineland palatine & 0.01235 & 4 & 1 & \\
\hline 8 & Endausbau & Final buildup & 0.01227 & 4 & & \\
\hline 9 & Gemeinschaftszollamt & Common customs office & 0.00967 & 4 & & \\
\hline 10 & Derzeitig & Current & 0.00938 & 4 & & \\
\hline 11 & Ausgleichsberechtigten [Länder] & [states] entitled to equalization & 0.00935 & 4 & & 1 \\
\hline 12 & Ungleichgewichte & Disequilibria & 0.00775 & 4 & & \\
\hline 13 & Strukturschwachen [Regionen] & Structurally weak [regions] & 0.00760 & 4 & & 1 \\
\hline 14 & Kreis & County & 0.00709 & 4 & & 1 \\
\hline 15 & Hochschulen & Higher education institutions & 0.00661 & 4 & & \\
\hline 16 & Raumordnungsbericht & Spatial Planning Report & 0.00648 & 4 & & \\
\hline 17 & Bezugsfertigkeit & Readiness for moving in & 0.00626 & 4 & & \\
\hline 18 & Bmbau & Federal Ministry for Construction & 0.00617 & 4 & & \\
\hline 19 & Gemeinschaftsaufgabe & Common task & 0.00595 & 4 & & \\
\hline 20 & Kampagne & Campaign & 0.00533 & 4 & & \\
\hline 21 & Frankfurt & Frankfurt & 0.00522 & 4 & 1 & \\
\hline 22 & Weitergeltender & Continuing to be in force & 0.00485 & 4 & & \\
\hline
\end{tabular}


Table 2, continued

\begin{tabular}{|c|c|c|c|c|c|c|}
\hline Nr. & Words identified by the NMF model & Translation & $\begin{array}{l}\text { Frequency } \\
\text { weight }\end{array}$ & Topic & $\begin{array}{l}\text { Named spatial } \\
\text { entities }\end{array}$ & $\begin{array}{c}\text { Spatial } \\
\text { categories }\end{array}$ \\
\hline 23 & Zollamt & Custom office & 0.00476 & 4 & & \\
\hline 24 & Kwea [Kreiswehrersatzamt] & Conscription office & 0.00459 & 4 & & \\
\hline 25 & Bundesbahn & Federal Railway & 0.00437 & 4 & & \\
\hline 26 & Teilplan & Part of a plan & 0.00394 & 4 & & \\
\hline 27 & Fortschreibung & Update & 0.00383 & 4 & & \\
\hline 28 & Raumordnungskommission & Spatial Planning Commission & 0.00354 & 4 & & \\
\hline 29 & Nordrheinwestfalen & North Rhine Westphalia & 0.00274 & 4 & 1 & \\
\hline 30 & Bundesraumordnungsprogramm & Federal Spatial Planning Program & 0.00253 & 4 & & \\
\hline 31 & Forschung & Research & 0.00217 & 4 & & \\
\hline 32 & Einrichtung & Installment & 0.00112 & 4 & & \\
\hline 33 & Problemregionen & Problem regions & 0.00075 & 4 & & \\
\hline 34 & $\begin{array}{l}\text { Mkro } \\
\text { [Ministerkonferenz für Raumord- } \\
\text { nung] }\end{array}$ & $\begin{array}{l}\text { Conference of Ministers for Spatial } \\
\text { Planning }\end{array}$ & 0.00040 & 4 & & \\
\hline 35 & Wasservorkommen & Water sources & 0.00033 & 4 & & \\
\hline \multirow[t]{3}{*}{36} & Bauwesen & Construction trade & 0.00012 & 4 & & \\
\hline & Total & & & & 6 & 5 \\
\hline & \multicolumn{4}{|c|}{ Topic 5: Federal Spatial Planning Program (mainly 1972-1974) } & & \\
\hline 1 & Belastbarkeit & Carrying capacity & 0.01725 & 5 & & \\
\hline 2 & Germany & Germany & 0.01413 & 5 & 1 & \\
\hline 3 & Roggen & Rye & 0.01331 & 5 & & \\
\hline 4 & Hauptkommission [der MKRO] & $\begin{array}{l}\text { Main commission [of the Conference } \\
\text { of Ministers for Spatial Planning] }\end{array}$ & 0.01273 & 5 & & \\
\hline 5 & Entwicklungsachsen & Development axes & 0.01189 & 5 & & 1 \\
\hline 6 & Weizen & Wheat & 0.01019 & 5 & & \\
\hline 7 & Richtfunkverbindungen & Directional radio connections & 0.00914 & 5 & & \\
\hline 8 & Verkehrsspitzen & Traffic peaks & 0.00895 & 5 & & \\
\hline 9 & Michigan & Michigan & 0.00826 & 5 & 1 & \\
\hline 10 & Bundesraumordnungsprogramm & Federal Spatial Planning Program & 0.00697 & 5 & & \\
\hline 11 & Bayerischenstaatsministeriums & Bavarian State Ministry & 0.00679 & 5 & & \\
\hline 12 & Gesbl [Gesetzesblatt] & Official gazette & 0.00664 & 5 & & \\
\hline 13 & Futterbau & Forage cultivation & 0.00496 & 5 & & \\
\hline 14 & Entwicklungskonzeption & Development concept & 0.00488 & 5 & & \\
\hline 15 & Prognose & Prognosis & 0.00454 & 5 & & \\
\hline 16 & Ballungszonen & Agglomeration zones & 0.00446 & 5 & & 1 \\
\hline 17 & Rossmiller & Rossmiller & 0.00439 & 5 & & \\
\hline 18 & Futtergetreide & Forage cereal & 0.00386 & 5 & & \\
\hline 19 & $\begin{array}{l}\text { Staffelung [von Arbeits- und Unter- } \\
\text { richtszeiten] }\end{array}$ & $\begin{array}{l}\text { Grading [of work and school sched- } \\
\text { ules] }\end{array}$ & 0.00378 & 5 & & \\
\hline 20 & Problemstellung & Problem & 0.00372 & 5 & & \\
\hline 21 & Bek [Bekanntmachung] & Publication & 0.00360 & 5 & & \\
\hline 22 & Nahverkehrssysteme & Local transport systems & 0.00341 & 5 & & \\
\hline 23 & Hafer & Oats & 0.00319 & 5 & & \\
\hline 24 & Staatskanzlei & State chancellery & 0.00060 & 5 & & \\
\hline 25 & Bundesausbaugebiete & Federal investment areas & 0.00058 & 5 & & 1 \\
\hline 26 & Agrarprodukten & Agrarian products & 0.00044 & 5 & & \\
\hline 27 & Gleitenden & Floating & 0.00041 & 5 & & \\
\hline \multirow[t]{2}{*}{28} & $\begin{array}{l}\text { Gebietseinheit [der Bundesraumord- } \\
\text { nung] }\end{array}$ & $\begin{array}{l}\text { Territorial unit [of Federal Spatial } \\
\text { Planning] }\end{array}$ & 0.00037 & 5 & & 1 \\
\hline & Total & & & & 2 & 4 \\
\hline
\end{tabular}

At the same time, from 1978 onwards, the proportion of maps has increased at the expense of tables and, to a lesser extent, at the expense of figures. This development was further boosted with the report issued in 2000, when responsibility for the report was transferred from the ministry to the federal research institute BBSR. The relative increase in the proportion of maps remains un- changed in the reports from 2011 and 2017 when the total number of illustrations decreased. This observed shift in Spatial Planning Reports is no coincidence but seems to be part of a broader strategy of communicating policy advice in spatial planning [100]. Maps are visual representations that can usually also be read by laymen in a very intuitive way. At the same time, the 
Spatial Planning Report typically uses political maps as a base layer for depicting descriptive or analytical results. Political maps divide space into territories with clearly marked borders and often also label the state capital. Such depictions not only suggest the capital's ability to govern the territory but also implicitly address the individualized political territories as political actors capable of developing strategies for coping with their particular situation. In contrast, the construction of an analytical category would theoretically facilitate the establishment of interest groups that could lobby for the establishment of an indicator-based federal policy instrument favoring their interests [84,101].

\section{Summary and conclusions}

Against the backdrop of the increasingly ubiquitous use of indicators in society, this paper has sought to explain why this use has remained very limited when it comes to the guiding idea of equivalent living conditions in federal spatial policy in Germany. The idea has regained political attention in recent years, but it has not yet been operationalized with an agreed upon set of indicators. This is an especially interesting case because federal spatial planning is a policy field deeply imbued with indicators - typically produced by an expert organization that is concurrently exposed to both scientific and political expectations.

Drawing primarily on arguments derived from actornetwork theory, we assumed that indicators not only represent the world, but transform it by adding an objectifying description to it [45]. In the case of indicators that operationalize the rather ambiguous idea of equivalent living conditions, we assumed that it would convey a place-based problematization of regional disparities in a relatively broad range of dimensions, which could be formally associated with equalizing spatial policy schemes. We heuristically distinguished between four different levels of formalizing the observation of and intervention into regional disparities (informal use of indicators; explicit operationalization; explicit operationalization and regular monitoring; explicit operationalization and formal spatial intervention programs). We further assumed that indicators might compete with each other for political attention. In a competitive situation, indicators that represent well-defined or established concepts would be in a more advantageous position because they were associated with formal intervention programs than indicators that represent ambiguous or new concepts; indicators that have been integrated into causal models would be more influential than indicators that are merely descriptive. In contrast, indicators representing more ambiguous concepts would more likely remain at a level of informal use.

Empirically we have shown that the idea of equivalent living conditions has received considerable and controversial attention in the German parliament, while the Spatial Planning Report seems to have become a taken-for-granted source of information with trusted epistemic authority [10]. Why, then, have suggestions for measuring equivalent living conditions that were made in the reports from 2005 and 2011 not been taken up by the recent federal Commission on Equivalent Living Conditions?

In order to resolve this conundrum we analyzed the content of the Spatial Planning Report from 1963 to 2017. In the early 1970s, when the phrase 'equivalent living conditions' was coined, it was interpreted against the backdrop of 'backward' rural regions on the one hand, and possibly overburdened agglomeration zones on the other. In short, the focus was on raising living standards for all citizens and it was paired with the significant confidence in the steering capacity of the nation state. Economic structural change brought about a narrowing of federal spatial planning to regional economic policy from 1978 using GDP as the main intellectual tool of policy design. The political demand for equivalent living conditions did not reemerge until the 1990s, after the German unification and in the face of growing regional disparities. While it remained on a fairly low level during the 1990s, it has become more manifest since 2000 . This political debate can be interpreted in part as a result of the continuous objectifying monitoring of regional disparities in the Spatial Planning Report. After the turn of the millennium, the idea of equivalent living conditions within the Spatial Planning Report became especially embedded in transnational developments such as European integration, global competition and the discourse on sustainable development. Especially the latter contributed to an explicit operationalization of the idea of equivalent living conditions.

We explain the limited formalization of the idea of equivalent living conditions, which has not exceeded the first level of formalization that we defined for analytical purposes, by the interplay of three different factors. First, the rather ambiguous idea of equivalent living conditions faced competition from the more narrow idea of economic growth, which could count on the well-established GDP indicator [67]. Second, the assignment of the responsibility for the Spatial Plan- 
ning Report at the BBSR strengthened its scientific independence but also brought about less formalized forms of communicating analytical results to political addressees. This communicative strategy within the report corresponds with rather informal and participatory policy formulation, integrating experts and politicians in the framework of 'model projects' [11]. This informal way of policy formulation seems to be highly compatible with the entanglement of competences in German federalism [65]. Third, transnational issues and actor constellations, in particular the importance of indicators in the global discourse on sustainable development, catalyzed the explicit operationalization of the idea of equivalent living conditions in 2005 which was followed by a second proposal of formalization in 2011. A possible caveat to the proposals for operationalizing the idea of equivalent living conditions presented so far might be that both included economic indicators, in other words they would have built up a certain redundancy with existing regional economic policy programs had they become formally related to equalizing policy programs. Regional economic policy is quite a firmly established policy field that has recently become even more integrated in Germany [102]. Instead, a complementary set of indicators might avoid such competition, which is usually not only competition between indicators but also between the academic professions related to them.

Against this competitive backdrop it remains to be seen whether a stronger formalization of regional policy instruments that measure and monitor equivalent living conditions can be reached as proposed by the Equivalent Living Conditions Commission. The current translation of the Sustainable Development Goals to a national strategy for sustainable development does not seem to place great emphasis on subnational spatial disparities [103]. Yet, two factors might strengthen such an endeavor: First, starting in 2020 the European Union Statistics on Income and Living Conditions (EU-SILC) will contain indicators on subjective life satisfaction, allowing for causal analysis on a regional scale across member countries [99]. Hence, results from this type of analysis might strengthen a closer integration of national equalization policies on living conditions with EU territorial cohesion policy. Second, the apparent resilience of the fairly decentralized German healthcare system during the current Corona pandemic could also encourage a more formalized focus on the regional provision of public infrastructure.

The limited formalization of the idea of equivalent living conditions does not mean that the concept has no influence at all. Instead it seems to have a conceptual influence as demonstrated by the thematic focus of the Spatial Planning Report of 2017 on assuring minimum standards of infrastructure in especially sparsely populated and remote areas, and the official justification for initiating the federal Equivalent Living Conditions Commission [82].

What do we learn from this case study that we can apply to official statistics in the future? We would like to briefly sketch a few thoughts on the use of indicators. First, the use of indicators in the Spatial Planning Report shows that their visualization - especially in maps - is an important aspect that should not be overlooked with respect to their conceptual influence. Second, data from geographical information systems (GIS) will become even more important for spatial research in the future. Enhancing the interoperability of statistics that are based on administrative territorial units and GIS data appears essential. Last but not least, it has been suggested that "advanced analytics", such as topic modeling, could become a part of official statistics. While the present paper demonstrates that these techniques can be used for a kind of 'market research' of official statistics, the time needed to develop a professional and reflective practice should not be underestimated. Slogans, such as "data4policy" [1], suggest that there might be a shortcut for developing such a practice. However, it will be necessary to create specialized research capacities - within statistical offices or in cooperation with other actors - to point research and development in this direction.

\section{Acknowledgments}

We are grateful for the critical comments of Reinhold Sackmann and two anonymous reviewers from SJIAOS. Lorri King kindly took care of the copy editing. Any remaining shortcomings can be exclusively attributed to the authors.

\section{References}

[1] Radermacher WJ. Governing-by-the-numbers/Statistical governance: Reflections on the future of official statistics in a digital and globalised society. Stat J IAOS. 2019; 35(4): 519-537, doi: s103233/SJI-190562.

[2] Ho J-M. Social Statisticalization: Number, State, Science. Dissertation. Cornell University: New York, 2019.

[3] Porter TM. Trust in Numbers: The Pursuit of Objectivity in Science and Public Life. Princeton, NJ: Princeton University Press, 1995. 
[4] Rose NS. Numbers. In: Powers of freedom. Reframing political thought. Cambridge: Cambridge University Press, 1999; pp. 197-232.

[5] Mennicken A, Espeland WN. What's new with numbers? Sociological approaches to the study of quantification. Annu Rev Sociol. 2019; 45(1): 223-245, doi: 10.1146/annurev-soc073117-041343.

[6] Rottenburg R, Merry SE. A world of indicators: the making of governmental knowledge through quantification. In: Rottenburg R, Merry SE, Park S-J, Mugler J, editors. The World of Indicators. The Making of Governmental Knowledge through Quantification. Cambridge: Cambridge University Press, 2015, pp. 1-33.

[7] Kawka R. Der Deutschlandatlas. Ein Beispiel für wissenschaftliche Politikberatung. Informationen zur Raumentwicklung. 2019; (3): 49-55.

[8] Abrahams G. What "Is" Territorial Cohesion? What Does It "Do"? Essentialist Versus Pragmatic Approaches to Using Concepts. European Planning Studies. 2014; 22(10): 2134 2155, doi: 10.1080/09654313.2013.819838.

[9] Bayerischer Landtag. Bericht der Enquete-Kommission "Gleichwertige Lebensverhältnisse in ganz Bayern". München, 2017.

[10] Deutscher Bundestag. Antwort der Bundesregierung auf die Kleine Anfrage der Abgeordneten Markus Tressel, Britta Haßelmann, Christian Kühn (Tübingen), weiterer Abgeordneter und der Fraktion BÜNDNIS 90/DIE GRÜNEN: Stärkung strukturschwacher Regionen in Deutschland. Berlin, 2017.

[11] Einig K. Funktion und Folgen von Modellvorhaben für die Politikberatung. Informationen zur Raumentwicklung. 2011; (7-8): 435-452.

[12] Deutscher Bundestag. Raumordnungsbericht 2011. Berlin, 2012.

[13] Deutscher Bundestag. Raumordnungsbericht 2005. Berlin, 2005 .

[14] Deutscher Bundestag. Raumordnungsbericht 2000. Berlin, 2000 .

[15] Deutscher Bundestag. Raumordnungsbericht 1993. Bonn, 1993.

[16] Deutscher Bundestag. Raumordnungsbericht 1991. Bonn, 1991.

[17] Deutscher Bundestag. Raumordnungsbericht 1990. Bonn, 1990.

[18] Deutscher Bundestag. Raumordnungsbericht 1986. Bonn, 1986.

[19] Deutscher Bundestag. Raumordnungsbericht 1982. Bonn, 1982.

[20] Deutscher Bundestag. Raumordnungsbericht 1978. Bonn, 1978.

[21] Deutscher Bundestag. Raumordnungsbericht 1974. Bonn, 1974.

[22] Deutscher Bundestag. Raumordnungsbericht 1972. Bonn, 1972.

[23] Deutscher Bundestag. Raumordnungsbericht 1970. Bonn, 1970.

[24] Deutscher Bundestag. Raumordnungsbericht 1968. Bonn, 1968.

[25] Deutscher Bundestag. Raumordnungsbericht 1966. Bonn, 1966.

[26] Deutscher Bundestag. Erster Raumordnungsbericht. Bonn, 1963.

[27] Stichweh R. Wissen und das politische System. Bonn: Forum Internationale Wissenschaft (FIW), 2019.
[28] Weber M. Wirtschaft und Gesellschaft: Grundriss der verstehenden Soziologie, $5^{\text {th }}$ ed. Tübingen: Mohr Siebeck; 19211922.

[29] Laux H. Hybridorganisationen. Soziale Welt. 2016; 67(3): 313-332, doi: 10.5771/0038-6073-2016-3-313.

[30] Boswell C. Manufacturing political trust: Targets and performance management in public policy. Cambridge: Cambridge University Press, 2018

[31] Prévost J-G. Politics and Policies of Statistical Independence. In: Prutsch MJ, editor. Science, Numbers, and Politics. Cham: Springer, 2019, pp. 153-180.

[32] Rose R. The market for policy indicators. In: Shonfield A, Shaw S, editors. Social indicators and social policy. London: Heinemann, 1972, pp. 119-141.

[33] Knorr KD. Policymakers' Use of Social Science Knowledge Symbolic or Instrumental? In: Weiss $\mathrm{CH}$, editor. Using social research in public policy making. Lexington, MA: Lexington Books, 1977, pp. 165-182.

[34] Markusen A. Fuzzy concepts, scanty evidence, policy distance: The case for rigour and policy relevance in critical regional studies. Regional Studies. 1999; 33(9): 869-884, doi: 10.1080/00343409950075506.

[35] Simon HA. The structure of ill structured problems. Artif. Intell. 1973; 4(3-4): 181-201, doi: 10.1016/0004-370273900118.

[36] Rittel HWJ, Webber MM. Dilemmas in a general theory of planning. Policy Sciences. 1973; 4(2): 155-169.

[37] Spector M, Kitsuse JI. Constructing Social Problems, $2^{\text {nd }}$ ed New Brunswick, NJ: Transaction, 1987.

[38] Weiss CH. Research for policy's sake: The enlightenment function of social research. Policy Analysis. 1977; 3(4): 531545 .

[39] Weiss CH, Murphy-Graham E, Birkeland S. An alternate route to policy influence. American Journal of Evaluation. 2005; 26(1): 12-30, doi: 10.1177/1098214004273337.

[40] IAT, ZEFIR. Modellvorhaben der Raumordnung: Regionale Lebensverhältnisse - Messkonzept zur Bewertung ungleicher Lebensverhältnisse in den Teilräumen Deutschlands. Abschlussworkshop. Gelsenkirchen, 19.02.2020.

[41] Desrosières A. The politics of large numbers: A history of statistical reasoning. Cambridge, MA: Harvard University Press, 1993.

[42] Bourdieu P. Rethinking the state: Genesis and structure of the bureaucratic field. Sociological Theory. 1994; 12(1): 1-18.

[43] Foucault M. Die Geburt der Biopolitik. Frankfurt (Main): Suhrkamp, 2004

[44] Latour B. Science in action: How to follow scientists and engineers through society. Cambridge, MA: Harvard University Press, 1987

[45] Didier E. Do Statistics "Perform" the Economy? In: MacKenzie DA, Muniesa F, Siu L, editors. Do economists make markets? On the performativity of economics. Princeton: Princeton University Press, 2007, pp. 276-310.

[46] Loveman M. National colors. Racial classification and the state in Latin America. Oxford: Oxford University Press, 2014.

[47] Bhagat RB. Census enumeration, religious identity and communal polarization in India. Asian Ethnicity. 2013; 14(4): 434-448, doi: 10.1080/14631369.2012.710079.

[48] van Dooren W, Bouckaert G, Halligan J. Non-use. In: Performance management in the public sector, $2^{\text {nd }}$ ed. London: Routledge, 2010, pp. 154-173.

[49] Loveman M. The modern state and the primitive accumu- 
lation of symbolic power. American Journal of Sociology. 2005; 110(6): 1651-1683, doi: 10.1086/428688.

[50] Simon P. The Choice of Ignorance: The Debate on Ethnic and Racial Statistics in France. In: Simon P, Piché V, Gagnon A, editors. Social Statistics and Ethnic Diversity: Cross-National Perspectives in Classifications and Identity Politics. Cham: Springer, 2015, pp. 65-88.

[51] Lehtonen M. The non-use and influence of UK Energy Sector Indicators. Ecol Indic. 2013; 35: 24-34, doi: 10.1016/ j.ecolind.2012.10.026.

[52] Boulanger PM. Political uses of social indicators: Overview and application to sustainable development indicators. Int J Sustainable Dev. 2007; 10(1/2): 14, doi: 10.1504/IJSD.2007. 014411.

[53] Mayntz R. Zählen - Messen - Entscheiden: Wissen im politischen Prozess. Köln: MPIfG, 2017.

[54] Merry SE. Measuring the World: Indicators, Human Rights, and Global Governance. In: Malito DV, Umbach G, Bhuta $\mathrm{N}$, editors. The Palgrave Handbook of Indicators in Global Governance. Cham: Springer, 2018, pp. 477-501.

[55] Bartl W, Papilloud C, Terracher-Lipinski A. Governing by numbers: Key indicators and the politics of expectations. An Introduction. Historical Social Research. 2019; 44(2, Special Issue): 7-43, doi: 10.12759/hsr.44.2019.2.7-43.

[56] Lehtonen M, Sébastien L, Bauler T. The multiple roles of sustainability indicators in informational governance: Between intended use and unanticipated influence. Current Opinion in Environmental Sustainability. 2016; 18: 1-9, doi: 10.1016/j.cosust.2015.05.009.

[57] Lampland M. False numbers as formalizing practices. Social Studies of Science. 2010; 40(3): 377-405, doi: 10.1177/ 0306312709359963.

[58] Heintz B. Die Herrschaft der Regel: Zur Grundlagengeschichte des Computers. Frankfurt (Main): Campus, 1993.

[59] Desrosières A. Words and Numbers. In: Sætnan AR, Lomell HM, Hammer S, editors. The mutual construction of statistics and society. New York, NY: Routledge, 2011, pp. 41-63.

[60] Lascoumes P, Le Galès P. Introduction: Understanding Public Policy through its Instruments - From the Nature of Instruments to the Sociology of Public Policy Instrumentation. Governance. 2007; 20(1): 1-21, doi: 10.1111/j.14680491.2007.00342.x.

[61] Ahrne G, Brunsson N. Organization outside organizations: the significance of partial organization. Organization. 2011; 18(1): 83-104, doi: 10.1177/1350508410376256.

[62] Starr P. The Sociology of Official Statistics. In: Alonso W, Starr P, editors. The politics of numbers. New York: Russell Sage Foundation, 1987, pp. 7-57.

[63] Miller P. Governing by numbers: Why calculative practices matter. Social Research. 2001; 68(2): 379-396.

[64] Thévenot L. Rules and implements: Investment in forms. Social Science Information. 1984; 23(1): 1-45, doi: $10.1177 / 053901884023001001$.

[65] Scharpf FW, Reissert B, Schnabel F. Politikverflechtung: Theorie und Empirie des kooperativen Föderalismus in der Bundesrepublik. Kronberg (Taunus): Scriptor Verlag, 1976.

[66] Bartl W. Institutionalization of a formalized intergovernmental transfer scheme for asylum seekers in Germany: The königstein key as an indicator of federal justice. Journal of Refugee Studies. 2019, doi: 10.1093/jrs/fez081.

[67] Lepenies P. The Power of a Single Number: A Political History of GDP. New York, NY: Columbia University Press, 2016.
[68] Büttner SM. Mobilizing regions, mobilizing Europe: Expert knowledge and scientific planning in European regional development. London: Routledge, 2012.

[69] Deutscher Bundestag [homepage on the Internet]. Drucksachen und Plenarprotokolle des Bundestages - ab 1949 [cited 2019 December 1]. Available from: https://pdok.bundestag.de/.

[70] ARL. Gleichwertigkeit der Lebensverhältnisse - der Beitrag von Raumordnung und Raumentwicklung. Berlin, 20.11.2019.

[71] Baur N, Kelle U, Kuckartz U. Mixed Methods - Stand der debatte und aktuelle problemlagen. KZfSS Kölner Zeitschrift für Soziologie und Sozialpsychologie. 2017; 69(2): 1-37, doi: 10.1007/s11577-017-0450-5.

[72] Papilloud C. [homepage on the Internet]. MTA - Multi Text Analyser, [updated 2017-2020; cited 2020 March 10]. Available from: https://cp.soziologie.uni-halle.de/MTA/doku.php.

[73] Kuckartz U. Qualitative text analysis: A guide to methods, practice \& using software. Los Angeles: Sage, 2014.

[74] Diekmann A. Empirische Sozialforschung: Grundlagen, Methoden, Anwendungen, $20^{\text {th }}$ ed. Reinbek bei Hamburg: Rowohlt, 2009.

[75] Papilloud C, Hinneburg A. Qualitative Textanalyse mit TopicModellen: Eine Einführung für Sozialwissenschaftler. Wiesbaden: Springer VS, 2018.

[76] Rodriguez D. [homepage on the Internet]. word2vec, [updated 2018 September 5; cited 2020 March 10]. Available from: https//pypi.org/project/word2vec/.

[77] Zimmermann H. What is a "Leitbild"? Some Reflections on the Origin and Use of the German Expression. In: Strubelt W, editor. Guiding Principles for Spatial Development in Germany. Berlin: Springer, 2009, pp. 3-14.

[78] Leendertz A. Der Gedanke des Ausgleichs und die Ursprünge des Leitbildes der "gleichwertigen Lebensbedingungen". In: Mäding H, Strubelt W, editors. Vom Dritten Reich zur Bundesrepublik. Hannover: Akademie für Raumforschung und Landesplanung (ARL), 2009, pp. 210-225.

[79] Mießner M. "Gleichwertigkeit der Lebensverhältnisse". Zum Aufstieg eines leeren Signifikanten. Planung Neu Denken. 2016; (1): 1-10.

[80] Manderscheid K, Richardson T. Planning inequality: Social and Economic Spaces in National Spatial Planning. European Planning Studies. 2011; 19(10): 1797-1815, doi: 10.1080/09654313.2011.614388.

[81] Leendertz A. Vom Anfang und Ende einer wissenschaftlichadministrativen Mission. Archiv für Sozialgeschichte. 2010; 50: 69-107.

[82] Kerber M. Vorstellung der Ergebnisse der Regierungskommission. Gleichwertigkeit der Lebensverhältnisse - der Beitrag von Raumordnung und Raumentwicklung. Berlin: ARL, 20.11.2019.

[83] Hellstern G-M, Wollmann H. Die Raumordnungsberichte der Bundesregierung. Quellenlektüre als Zugang zur Politikanalyse. Leviathan. 1976; 4(2): 231-255.

[84] Scharpf FW, Schnabel F. Steuerungsprobleme der Raumplanung. In: Bruder W, Ellwein T, editors. Raumordnung und staatliche Steuerungsfähigkeit. Opladen: Westdeutscher Verlag, 1980, pp. 12-57.

[85] Volkmann A. Gleichwertige Lebensverhältnisse zwischen Daseinsvorsorge und räumlichen Verwirklichungschancen. Dissertation. Technische Universität Dortmund: Dortmund, 2018.

[86] Strubelt W. Gleichwertigkeit der Lebensverhältnisse als Element der sozialen Integration. In: Kecskes R, Wagner M, 
Wolf C, editors. Angewandte Soziologie. Wiesbaden: VS Verlag für Sozialwissenschaften, 2004, pp. 247-285.

[87] Rosenfeld MTW. Gleichwertigkeit der Lebensverhältnisse. In: Blotevogel HH, Döring T, Grotefels S, Helbrecht I, Jessen J, Schmidt C, editors. Handwörterbuch der Stadt- und Raumentwicklung. Hannover: Akademie für Raumforschung und Landesplanung, 2018, pp. 837-849.

[88] Blotevogel HH. Zum Verhältnis der regionalökonomischen Zentrale-Orte-Theorie zum Zentrale-Orte-Konzept der Raumordnung. In: Blotevogel HH, editor. Fortentwicklung des Zentrale-Orte-Konzepts. Hannover: Akademie für Raumforschung und Landesplanung (ARL), 2002, pp. 10-16.

[89] Sinz M. Bundesraumordnung. In: Blotevogel HH, Döring T, Grotefels S, Helbrecht I, Jessen J, Schmidt C, editors. Handwörterbuch der Stadt-und Raumentwicklung. Hannover: Akademie für Raumforschung und Landesplanung, 2018, pp. 325-336.

[90] Strubelt W. Reflections on Leitbilder. In: Strubelt W, editor. Guiding Principles for Spatial Development in Germany. Berlin: Springer, 2009, pp. 201-209.

[91] Barlösius E. Gleichwertig ist nicht gleich. Aus Politik und Zeitgeschichte. 2006; 37: 16-23.

[92] Brake K. "Gleichwertigkeit der Lebensverhältnisse" und Wirkungskräfte der Raumstrukturierung. Raumforschung und Raumordnung. 2007; 65(3): 175-185, doi: 10.1007/BF0318 4543.

[93] Sackmann R, Bartl W, Jonda B, Kopycka K, Rademacher C. Coping with demographic change. A comparative view on education and local government in Germany and Poland. Dordrecht: Springer, 2015.

[94] Beirat für Raumordnung. Gesellschaftliche Indikatoren für die Raumordnung. In: Empfehlungen vom 16. Juni 1976 Bonn, 1976, pp. 27-60.
[95] Berking H, Löw M, editors. Die Eigenlogik der Städte: Neue Wege für die Stadtforschung. Frankfurt (Main): Campus, 2008.

[96] Winkler-Kühlken B, Milbert A. Zwei Perspektiven aus Raumplanung und Raumbeobachtung. Aus Politik und Zeitgeschichte. 2019; 69(46): 19-31.

[97] Kersten J, Neu C, Vogel B. Regionale Daseinsvorsorge. Begriff, Indikatoren, Gemeinschaftsaufgabe: Gutachten im Auftrag der Abteilung Wirtschafts-und Sozialpolitik der Friedrich-Ebert-Stiftung. Bonn, 2015.

[98] Kawka R. Gleichwertigkeit messen. Informationen zur Raumentwicklung. 2015; (1): 71-82.

[99] BMI, BMEL, BMFSFJ. Unser Plan für Deutschland - Gleichwertige Lebensverhältnisse überall. Berlin: Bundesministerium des Innern, für Bau und Heimat, 2019.

[100] Sinz M. Raumordnung als Gegenstand von Politikberatung ein Erfahrungsbericht. Informationen zur Raumentwicklung. 2011; (7/8): 471-486.

[101] Kawka R, Staats J-U. Metropolregionen und Bundesraumordnung. Informationen zur Raumentwicklung. 2016; (5): 535541.

[102] Die Bundesregierung [homepage on the Internet]. Das gesamtdeutsche Fördersystem für strukturschwache Regionen, [updated 2020 March 31; cited 2020 April 29]. Available from: https://www.bmwi.de/Redaktion/DE/Down loads/G/gesamtdeutsches-foerdersystem-fuer-strukturschwa che-regionen.pdf.

[103] Die Bundesregierung [homepage on the Internet]. Ziele für nachhaltige Entwicklung: Weniger Ungleichheiten, [updated 2019 February 28; cited 2020 April 8]. Available from: https//www.bundesregierung.de/breg-de/themen/ nachhaltigkeitspolitik/weniger-ungleichheiten-1592836. 